\title{
Review \\ Singular Adult Neural Stem Cells Do Not Exist
}

\author{
David Petrik ${ }^{1, *(D)}$, Sara Jörgensen ${ }^{1}$, Vasileios Eftychidis ${ }^{1,2} \mathbb{D}$ and Florian A. Siebzehnrubl 1,2,*(D) \\ 1 School of Biosciences, Cardiff University, Cardiff CF10 3AX, UK; jorgensens1@cardiff.ac.uk (S.J.); \\ eftychidisv@cardiff.ac.uk (V.E.) \\ 2 School of Biosciences, European Cancer Stem Cell Research Institute, Cardiff University, \\ Cardiff CF24 4HQ, UK \\ * Correspondence: petrikd@cardiff.ac.uk (D.P.); fas@cardiff.ac.uk (F.A.S.)
}

Citation: Petrik, D.; Jörgensen, S.; Eftychidis, V.; Siebzehnrubl, F.A.

Singular Adult Neural Stem Cells Do Not Exist. Cells 2022, 11, 722.

https://doi.org/10.3390/

cells11040722

Academic Editor: Cord Brakebusch

Received: 3 December 2021

Accepted: 10 February 2022

Published: 18 February 2022

Publisher's Note: MDPI stays neutral with regard to jurisdictional claims in published maps and institutional affiliations.

Copyright: (C) 2022 by the authors. Licensee MDPI, Basel, Switzerland. This article is an open access article distributed under the terms and conditions of the Creative Commons Attribution (CC BY) license (https:// creativecommons.org/licenses/by/ $4.0 /)$.

\begin{abstract}
Adult neural stem cells (aNSCs) are the source for the continuous production of new neurons throughout life. This so-called adult neurogenesis has been extensively studied; the intermediate cellular stages are well documented. Recent discoveries have raised new controversies in the field, such as the notion that progenitor cells hold similar self-renewal potential as stem cells, or whether different types of aNSCs exist. Here, we discuss evidence for heterogeneity of aNSCs, including short-term and long-term self-renewing aNSCs, regional and temporal differences in aNSC function, and single cell transcriptomics. Reviewing various genetic mouse models used for targeting aNSCs and lineage tracing, we consider potential lineage relationships between Ascl1-, Gli1-, and Nestintargeted aNSCs. We present a multidimensional model of adult neurogenesis that incorporates recent findings and conclude that stemness is a phenotype, a state of properties that can change with time, rather than a cell property, which is static and immutable. We argue that singular aNSCs do not exist.
\end{abstract}

Keywords: neural stem cells; adult neurogenesis; cell lineage tracing; clonal analysis; cell heterogeneity; transcriptomics; self-renewal; neural progenitors

\section{Introduction}

"Singularity is almost invariably a clue. The more featureless and commonplace a crime is, the more difficult it is to bring it home". This is a quote from Sir Arthur Co-nan Doyle's Sherlock Holmes story, "The Boscombe Valley Mystery". The conundrum to solve here is the stemness of aNSCs. We wish that aNSCs possess unique, singular properties, which undoubtedly identify them. However, the latest results suggest that their features are more commonplace, and that it is difficult to define what an aNSC is.

\section{Adut Neurogenic Niches}

aNSC exist in three discrete areas, so-called 'niches', of the adult mammalian brain: in the subgranular zone (SGZ) of the hippocampus, in the subventricular zone (SVZ) of the lateral ventricles, and in the walls of the 3rd ventricle (3V) surrounded by the hypothalamus [1-4], which we name here as the hypothalamic ventricular zone (HVZ). These niches are conserved in many mammalian species. The adult HVZ niche was observed in mice, rats, sheep [5], lemurs, and humans as containing aNSC marker-expressing ependymocytes called tanycytes [6-8]. Mice, rats, lemurs, and humans share a restricted co-expression of aNSC markers in the HVZ, but humans show an additional three aNSC populations [9]. In adult mice, lineage tracing studies confirm that tanycytes generate new neurons in the hypothalamus, including in the arcuate $(\mathrm{ArcN})$ and ventromedial nuclei (VMN) [10-12]. In a comparative study of ovine, mouse, and human hypothalamus, Battalier et al., observed immature doublecortin (DCX)-positive and mature, Human Neuronal Protein C and D (HuC/D)-positive neurons occurring in hypothalamic nuclei [5]. This neurogenic potential of tanycytes in adult mice is further supported by their expression of the neurogenesis related protein doublecortin-like (DCL) [13], which was shown to co-localize with DCX 
in the mouse SVZ and SGZ [13,14]. In addition to rodents, SVZ and SGZ neurogenic niches have been confirmed in most mammalian species $[15,16]$. New neurons in the SGZ were confirmed by BrdU cell tracing in non-human primates [17] and by ${ }^{14} \mathrm{C}$ dating in humans [18].

\section{Neurogenic Rates in Different Niches}

The rate of adult neurogenesis varies between the neurogenic niches and mammalian species. In the SGZ, neurogenesis accounts for an annual turnover rate of around 10-14\% of hippocampal neurons in mice [18-20] and 1.75\% in humans [18]. In contrast to the SGZ, although more than tens of thousands of neuroblasts migrate into the olfactory bulb from the SVZ every day, only a fraction survive to complete their differentiation [21]. Despite this low survival rate, all neurons in the deeper layers of mouse OB can be replaced in 12 months [22]. Adult neurogenesis in the HVZ is often reported as having much smaller cell turnover than both SGZ and SVZ, ranging between 1-37\% [23]. However, this turnover can reach over $50 \%$ during the first 2.5 months of age in mice [24], which represents a significant neurogenic potential. It is important to consider that the rate of neurogenesis differs between species. New neurons daily produced in the SGZ count 9000 in rodents [25], 1300 in monkeys [26], and 700 in humans [18].

\section{What Is a Stem Cell?}

A stem cell has two key identifying properties. It is self-renewing and exhibits cellular potency for differentiated progenies. More elaborate definitions and stem cell properties have been formulated since the seminal discovery of the adult stem cells by Till and McCulloch [27,28]. However, given the latest research findings [29-31], we must ask if aNSCs fit this definition of self-renewing cells with cell lineage potency. In other words, is there a singular aNSC, or do we need to revisit our understanding of stemness in the adult brain?

As we discussed above, aNSCs from these niches differ in many of their properties including their cell dynamics, ontogeny, and origin. aNSCs in the SGZ (so called Type-1 cells) originate from neural progenitors developed (E16.5 in mice) from the dentate gyrus neuroepithelium [32]. During the early postnatal development, aNSCs are established from these dentate gyrus progenitors, which express Nestin or Hopx [33,34]. Similar to the SGZ, aNSCs of SVZ (so called B1 cells) are also generated from the embryonic neuroepithelium. Between E13.5 and E15.5 in mice, radial glia cells from the ventricular zone, which act as Pax6+ embryonic neural stem cells [35], give rise to aNSCs of the adult SVZ [36,37]. Finally, the origin of aNSCs (tanycytes) of the adult HVZ is traced to Sonic Hedgehog (Shh)-expressing progenitors from the embryonic floorplate [38,39].

Despite these ontogenic differences, all aNSCs can self-renew and possess the potency to generate one or more types of differentiated cell progeny. However, how many selfrenewing cell divisions are necessary to satisfy the definition of self-renewal, especially if the cell's life span is shorter than life span of the organism? Furthermore, would the ability of certain aNSCs to generate only one type of differentiated cells, so called 'unipotency', fulfil the rigorous definition of stem cells?

\section{Stem Cell Traits in Progenitor Cells}

The seminal paper by Encinas et al. [40] suggested that Nestin-expressing aNSCs in the SGZ only undergo three asymmetrical divisions to generate a progenitor cell. This implies that aNSCs, which do not last but terminally differentiate into an astrocyte, are, therefore, incapable of prolonged self-renewal. Such non-self-renewing aNSCs cannot be considered as stem cells. In contrast, another seminal study by Bonaguidi et al. [41] concluded that SGZ aNSCs also expressing Nestin are capable of asymmetric cell divisions and sustained self-renewal over almost the entire lifespan of the animal. While some of the differences between these two studies can be attributed to technical approaches (e.g., population vs. clonal analysis [42]), these studies revealed that not all aNSCs are the 
same in their self-renewal and potency. Indeed, hippocampal aNSCs expressing Nestin or the astrocyte-specific glutamate/aspartate transporter (GLAST) displayed different cell dynamics for generating adult-born neurons [43]. This suggests not only differential proliferation, quiescence, and self-renewal in the aNSC pool, but raises a question of stemness among aNSCs. To paraphrase- - not all aNSCs uphold a rigorous definition of stem cells [44], something that is well-recognized in developmental biology, where "the origin of stem cell populations from progenitor cells does occur repeatedly in normal development with respect to the formation of the various types of tissue-specific stem cell" [45]. This apparent difference between aNSCs and their daughter progenitor cells is removed in a more encompassing term 'neural stem and progenitor cells' (NSPCs) used in both adult and embryonic neurogenesis [46,47]. Indeed, the ground-breaking work of Pilz et al. [29] showed that the so-called 'transiently amplifying progenitors' (TAPs or Type- 2 cells) are capable of extended symmetric divisions, blurring the distinction between stem cells and progenitors. In addition, Pilz et al., observed that the so-called radial glia cell (RGC)-like aNSCs (Type- 1 cells) sometimes directly differentiated into two neuronal cells. These two findings challenge not only the very definition of aNSCs and their stemness, but also the linear model of adult neurogenesis in SGZ [48].

\section{A Limited Warranty of Stemness}

A more recent study from the Jessberger lab [30] compared NSPCs using Ascl1 or Gli1 as genetic driver and demonstrated that these subpopulations differ in their self-renewal capacity; Ascl1-targeted cells were eventually lost after activation (consistent with the Encinas model), while Gli1-targeted cells showed long-term self-renewal and persistence (consistent with the Bonaguidi model). Together, these findings seem to indicate that there are long-term and short-term self-renewing aNSC populations in the hippocampus. This idea is supported by a recent report from the Bonaguidi lab comparing Nestin-targeted versus Ascl1-targeted aNSCs that demonstrated that Nestin-targeted aNSCs had capacity for long-term self-renewal while Ascl1-targeted aNSCs persisted only short-term [31]. It remains to be resolved whether Gli1-expressing aNSCs are giving rise to a short-term selfrenewing, Ascl1-expressing stem cell subpopulation, or whether Gli1- and Ascl1-expressing aNSCs constitute separate entities. In addition, long term cell lineage tracing and clonal analysis experiments with the Gli1-CreER ${ }^{\mathrm{T} 2}$ line need to be performed to confirm if Gli1+ aNSCs display extended longevity. So far, lineage tracing with the Gli1-CreER ${ }^{\mathrm{T} 2}$ line was done for only 5 days [40], which is too short to address the longevity of Gli1+ aNSCs. It is further noteworthy that, so far, Aslc1-targeted, short-term aNSCs appear to generate only neuronal progenies, while Gli1- or Nestin-targeted long-term aNSCs make neurons and astrocytes.

Because of the stemness of neural progenitors, we can say that aNSCs possess limited warranty not only of their self-renewal but of their identity. We can also contemplate if what we call a neural progenitor may be a stem cell with temporarily limited or acquired self-renewal capacity. Thus, a stem cell is not a cell type but rather a phenotype, a state of properties that changes with time and interventions. However, if both aNSCs and progenitors can self-renew, which one is the stem cell, or are they both stem cells? Or, is only the original mother cell in the aNSC lineage the true stem cell, which we should define by another term, such as 'root cell'?

\section{Stemness as a Phenotype}

The property of stemness is usually seen through the prism of cell heterogeneity. For example, Ascl1 expressing aNSCs rapidly proliferate in the juvenile SGZ but increase their quiescence and self-renewal with age because of Ascl1 depletion over time [31,49,50]. In contrast to Ascl1-positive aNSCs, Nestin or Gli1 aNSCs in SGZ are more quiescent and last longer [30,31]. Reduction in Ascl1 expression over time, thus, promotes the stem cell phenotype, whereas Nestin or Gli1 aNSCs retain their stem cell phenotype and a higher quiescence over time. This perceived stem cell heterogeneity is a consequence of 
reductionistic approaches, which are necessary for technical and practical reasons. However, these apparently discrete aNSC subpopulations may be intermingled as we discuss in greater details below.

The field of multipotent hematopoietic stem cells (HSCs), which originated the stem cell field [49], offers an alternative perspective on self-renewal and stemness of aNSCs. There are dormant HSCs, which divide only five times over the lifetime of a mouse and can reversibly switch between active self-renewal and dormancy, maintaining a reservoir of most potent stem cells [50]. A deeply quiescent population of NSCs in the SVZ divide only every 3-5 months, comparable to the dormant HSCs [51]. Is it possible that some of the quiescent aNSCs in the hippocampus, such as the Nestin or Gli1 expressing aNSCs [30,31], can repeatedly re-enter quiescence after a period of proliferation? Are these the 'dormant' aNSCs that maintain the so-called 'neurogenic reserve' [52]? Stemness may be adopted transiently as observed in neural progenitors [29] or elicited by injury even in cells that are not considered stem cells under physiological conditions, such as astrocytes (reviewed by [53]). However, this perspective of stemness as a phenotype and not a cell type brings us back to the opening question: how many (and for what period) self-renewing cell divisions are needed to define a cell as a stem cell?

\section{Heterogeneity of Cell Potency}

Unlike pluri-potent and multi-potent stem cells, including embryonic NSCs (reviewed in [47]), aNSCs potency or lineage differentiation is predominantly directed to specific neuron subtypes in vivo. This is particularly true in the SGZ, where aNSCs exclusively generate the granule cell neurons but not any other type of neurons, including dozens of types of interneurons of the dentate gyrus [54]. aNSCs in the SGZ possess an astrogliogenic capacity, which would make them bi-potent. However, as with self-renewal, it remains to be determined if this astrogliogenesis is confined to discrete aNSC subpopulations [31,41] or is the terminal, exhaustive differentiation step [40]. Using clonal analysis in GLASTexpressing aNSCs, we found a 2:1 ratio of active clones generating only neurons versus bi-potent clones [55]. When comparing terminally differentiated clones, this ratio changed to 10:1 in favour of neuron-only clones (unpublished observation), which may indicate that terminal differentiation into astrocytes is a rare event, at least in young adult mice. The frequency of neuron-only producing clones declines with age in favour of aNSC quiescence, while bi-potent clones seem to disappear completely in aged mice [31]. Because GLAST also targets parenchymal astrocytes, we could not quantify clones that may have terminally differentiated only into astrocytes. Interestingly, the recent in vivo imaging studies rarely observed astrogliogenesis in different hippocampal aNSCs subpopulations [29,30]. Ascl1 expressing aNSCs generate only neurons, whereas Gli1 expressing aNSCs can generate rare astrocytes [30]. By contrast, astrogliogenesis is a common feature of Nestin-targeted aNSCs [31]. This may imply the existence of different aNSC subtypes, with short-term aNSCs (Ascl1-positive) likely restricted to the neuronal lineage, while long-term aNSCs (Gli1- or Nestin-positive) generate both neurons and astrocytes.

In the SVZ and the HVZ, aNSC potency may be broader. Distinct, aNSCs in the SVZ (Type-B cells) generate a spectrum of olfactory interneurons [56] and possess an oligodendrogliogenic potency [57], a feature that is confined to a unique aNSC subpopulation [58]. In the HVZ, aNSCs can generate different types of neurons, such as proopiomelanocortin (POMC) or neuropeptide Y (NPY)-expressing neurons [12,59]. Given the potency diversity among aNSC subpopulations, even in a single niche, questions arise about how the potency defines their stemness. Is unipotency enough to define a stem cell, especially if it is shortlived? Are the unipotent, short-term aNSCs a subset, or even daughter cells, of bi-potent (or multipotent) long-term aNSCs? Or are there also different types of long-term aNSCs, each restricted to a single lineage (neuron or astrocyte)? Moreover, is the level of potency a phenotype, which is determined by time and interventions, as we suggested in the case of self-renewal? The very concept of aNSC potency also depends on how discriminately we define the differentiated cells in the cell lineage. Clearly, we can distinguish between 
astrocytes and neurons. However, can the capacity to generate distinct, yet ontogenetically or functionally similar neuronal subtypes be considered as multi-potency? These questions are not just an issue of semantics; they cause us to contemplate the very concepts of stem cell potency and stemness.

\section{Stem Cell Heterogeneity from Single Cell Analyses}

In the previous sections, we deliberated whether discrete subpopulations of aNSC exist in one or more neurogenic niches. Recent advances in single cell profiling provide some answers to this question (Table 1). Single cell transcriptomics has unveiled the diversity of aNSCs within the same niche, including aNSC subpopulations within the SVZ that are regionally separated and that produce different neuronal subtypes [60,61]. By contrast, while aNSCs in the SGZ constitute a heterogeneous cell population, no discrete subpopulations could be defined based on single cell profiling so far $[62,63]$. Instead, hippocampal aNSCs show a spectrum of gene expression profiles, which can be resolved into quiescent vs. activated or diving vs. non-diving states $[30,62]$ but does not hint at discrete aNSC populations producing different progenies. This may be because the transcriptional profiles between different aNSC phenotypes are overlapping and, therefore, cannot be readily resolved without the use of specific Cre drivers to identify such aNSC states or phenotypes. Specific single cell analysis of Ascl1-targeted or Gli1-targeted aNSCs revealed that these two populations do not exhibit separable transcription profiles, even though small but important differences exist that may explain whether these cells return to quiescence or not [30]. Nevertheless, the largely overlapping transcriptional profiles of hippocampal aNSCs may indicate that stem cell phenotypes last temporarily instead of as discrete subpopulations of aNSCs. Whether there exist regional subtypes of aNSCs in the hippocampus (e.g., ventral vs. dorsal) that produce different progenies (e.g., neuronal vs. astroglial) remains elusive.

Table 1. Overview of single cell transcriptomics studies with a focus on aNSCs outside of a disease or transgenic model. DG: dentate gyrus; SVZ: subventricular zone; OB: olfactory bulb; TF: transcription factor.

\begin{tabular}{|c|c|c|c|c|}
\hline Reference & Region & Isolation and Sequencing & $\begin{array}{c}\text { aNSC } \\
\text { Hetero-Geneity }\end{array}$ & Notes \\
\hline$[63]$ & DG & $\begin{array}{l}\text { Microdissection; negative } \\
\text { selection (GluR1-, Cd24-); } \\
\text { SORT-seq }\end{array}$ & $\begin{array}{l}\text { quiescent v } \\
\text { activated }\end{array}$ & $\begin{array}{l}\text { Populations of quiescent and activated NSCs } \\
\text { could be defined, but no other heterogeneity }\end{array}$ \\
\hline$[30]$ & DG & $\begin{array}{l}\text { Intravital imaging, } \\
\text { Microdissection, } \\
\text { Gli1 / Ascl1-CreER }^{\mathrm{T} 2} \text {; } \\
\text { TdTomato, } \\
\text { Smart-seq2 }\end{array}$ & $\begin{array}{l}\text { quiescent v } \\
\text { activated }\end{array}$ & $\begin{array}{c}\text { Transcriptional differences partly overlapping } \\
\text { amongst two subpopulations of NSCs } \\
\text { (quiescent/activated) with a differential } \\
\text { self-renewal capacity. }\end{array}$ \\
\hline$[62]$ & DG & $\begin{array}{l}\text { Microdissection, } \\
\text { Nestin-CFPnuc, } \\
\text { SMART-seq }\end{array}$ & $\begin{array}{l}\text { quiescent v } \\
\text { activated }\end{array}$ & $\begin{array}{l}\text { Identified two super-groups with six } \\
\text { subgroups of NSC immediate progeny, } \\
\text { corresponding to quiescent/activated states. }\end{array}$ \\
\hline$[64]$ & $\begin{array}{l}\text { DG from embryonic } \\
\text { and adult between } \\
\text { E16.5 to P132 }\end{array}$ & $\begin{array}{c}\text { Microdissection, positive } \\
\text { selection (hGFAP-GFP+), } \\
\text { Fluidigm C1, 10X Chromium } \\
\text { V1/2, } \\
\text { Illumina HiSeq2000/2500/4000 }\end{array}$ & $\begin{array}{l}\text { developmental; } \\
\text { lineage; } \\
\text { young v aged }\end{array}$ & $\begin{array}{l}\text { Single cell profiling of cell types in DG across } \\
\text { prenatal, juvenile and adult. } \\
\text { Neuronal intermediate progenitors (nIPCs), } \\
\text { neuroblasts and immature granule cells did not } \\
\text { form separate clusters in the transition from } \\
\text { perinatal to adult, but radial glia molecularly } \\
\text { switch at P5 }\end{array}$ \\
\hline
\end{tabular}


Table 1. Cont.

\begin{tabular}{|c|c|c|c|c|}
\hline Reference & Region & Isolation and Sequencing & $\begin{array}{c}\text { aNSC } \\
\text { Hetero-Geneity }\end{array}$ & Notes \\
\hline [65] & DG & $\begin{array}{l}\text { Whole hippocampus dissection, } \\
\text { positive selection (ACSA-2+), } \\
\text { modified SMART-Seq2, Illumina } \\
\text { NextSeq } 500\end{array}$ & regional & $\begin{array}{l}\text { Astrocyte clustering into } 5 \text { subgroups reveals } \\
\text { intra- and inter-regional heterogeneity. Two } \\
\text { distinct clusters are defined, one cluster } \\
\text { spatially mapped to most GLAST+ cells in SGZ } \\
\text { and an intermediate GLAST+ progenitor } \\
\text { population mapped in subpial, stratum } \\
\text { lacunosum moleculare, and DG }\end{array}$ \\
\hline$[66]$ & SVZ & $\begin{array}{c}\text { Microdissection, } \\
\text { positive and negative selection } \\
(\text { Gfap-Gfp+, Prom1+, Egfr+/-, } \\
\text { Cd31-,Cd24-, Cd45-); } \\
\text { Fluidigm C1 Single-Cell Auto } \\
\text { Prep chip and SMARTer-seq }\end{array}$ & $\begin{array}{l}\text { quiescent v } \\
\text { activated }\end{array}$ & $\begin{array}{c}\text { Three NSC subpopulations across a spectrum } \\
\text { of activation/differentiation states. } \\
\text { Identified rare intermediate states with unique } \\
\text { molecular fingerprints. }\end{array}$ \\
\hline$[67]$ & SVZ & $\begin{array}{c}\text { Microdissection, } \\
\text { Nestin-CreER }{ }^{\mathrm{T} 2} \text { Histone } \\
\text { H2B-Gfp, Diphtheria toxin } \\
\text { receptor, } \\
\text { positive and negative selection } \\
\text { Glast+, Cd133+, Cd45-Cd95 }\end{array}$ & $\begin{array}{l}\text { quiescent v } \\
\text { activated; young v } \\
\text { aged }\end{array}$ & $\begin{array}{l}\text { Analysis of NSCs from infancy to old age to } \\
\text { identifies transition from quiescence to } \\
\text { proliferation and uncovers NSC heterogeneity. }\end{array}$ \\
\hline$[61]$ & SVZ & $\begin{array}{l}\text { Microdissection; hGFAP-GFP; } \\
\text { 10X Chromium V3 }\end{array}$ & regional & $\begin{array}{l}\text { Two populations of NSPCs in dorsal vs. ventral } \\
\text { V-SVZ are transcriptionally distinguishable. }\end{array}$ \\
\hline$[60]$ & $\begin{array}{c}\text { SVZ } \\
\text { Lateral v } \\
\text { Septal walls }\end{array}$ & $\begin{array}{c}\text { Microdissection, } \\
\text { hGFAP::CreER }{ }^{\mathrm{T} 2} ; \\
\text { R26RCAG-tdTomato', } \\
\text { Microwell and DROP-seq }\end{array}$ & $\begin{array}{l}\text { regional; male v } \\
\text { female }\end{array}$ & $\begin{array}{c}\text { Regional and sex differences between lateral } \\
\text { and septal wall NSCs. Distinct spatiotemporal } \\
\text { TF expression profiles of dormancy and lineage } \\
\text { progression across neurogenesis and } \\
\text { oligodendrogenesis. }\end{array}$ \\
\hline$[68]$ & $\begin{array}{l}\text { SVZ } \\
\text { OB }\end{array}$ & $\begin{array}{c}\text { Microdissection } \\
\text { GFAP-CreER }^{\mathrm{T} 2} \\
\text { Nestin-FlpER, } \\
\text { Microwell/DROP-seq and } \\
\text { SCOPE-seq }\end{array}$ & lineage & $\begin{array}{l}\text { Heterogeneous qNSCs with distinct OB } \\
\text { interneuron and astrocyte lineages. } \\
\text { Identified novel V-SVZ proliferation marker in } \\
\text { a transitory intermediate NSC population. }\end{array}$ \\
\hline$[69]$ & $\begin{array}{l}\text { Embryonic cortex } \\
\text { from } 4 \text { developmental } \\
\text { timepoints between } \\
\text { E11.5 to E17.5 }\end{array}$ & $\begin{array}{l}\text { Microdissection, } \\
\text { CD1 mice, } \\
\text { DROP-seq, } \\
\text { and FISH and immunostaining } \\
\text { Of adult V-SVZ }\end{array}$ & developmental time & $\begin{array}{c}\text { Identification of embryonic cortical radial } \\
\text { precursors with distinct transcriptional identity } \\
\text { which is maintained through their transition to } \\
\text { quiescence. A distinct E17.5 radial precursor } \\
\text { population transcriptionally similar to adult } \\
\text { V-SVZ qNSCs. }\end{array}$ \\
\hline
\end{tabular}

\section{Stem Cell Identity from Single Cell Analyses}

In several single cell profiling studies, transcriptomes from quiescent aNSCs and astrocytes show a high degree of overlap, reinforcing the close relationship between the two cell types and the notion of stem cells as specialised astrocytes [62,63]. A more recent single cell analysis of embryonic and early adult hippocampal cell types could separate aNSCs and astrocytes and their developmental trajectories [64]. A different single cell study identified five distinct astrocyte subtypes with a unique subset that could be linked to neurogenesis and another potential intermediate progenitor population [65]. Direct comparison of aNSCs across the three neurogenic niches using single cell OMICs may help determine the relationship and heterogeneity between SVZ, SGZ, and HVZ aNSCs. Cross-comparisons of stem cells at different developmental time points (embryonal, early postnatal, and adult) have highlighted that aNSCs are distinguishable from embryonic or juvenile stem cells, thus demonstrating the importance of developmental context beyond postnatal stages for adult neurogenesis [34,64].

Nevertheless, several limitations of single cell transcriptomics need to be considered. Currently, the read depth of single cell transcriptomics is much shallower compared to conventional RNA sequencing, which limits the ability to identify subpopulations based on rarer transcripts. The ability to discriminate rare subpopulations, such as heterogeneous aNSCs, further depends on the number of cells that are profiled. Earlier studies typically 
profiled fewer cells in total and were therefore less likely to identify smaller subpopulations. Additionally, apparent subpopulations on single cell cluster analyses may reflect a phenotypic diversity, rather than genuine subpopulations.

\section{Regional Heterogeneity of Stem Cells}

In addition to aNSC heterogeneity, regional organisation of aNSCs generating specific progenies was found in the SVZ, which affects production of neuronal subtypes as well as oligodendrocytes $[60,62,63]$. Single cell profiling studies show regionally different transcriptomes in aNSCs within the SVZ, but it remains unclear whether aNSC heterogeneity is influenced by regionally different microenvironments or by developmental programs [69]. Transient ablation of proliferating NSCs in the brain using chemical or radiation damage has demonstrated that the niche is repopulated from persisting, quiescent NSCs once the ablation is stopped $[43,51,70-73]$. However, such paradigms cannot evaluate the ability of aNSCs to repopulate different neurogenic niches. A combination of single cell profiling and transplantation studies may resolve this question eventually. When aNSCs from the SVZ were transplanted into the hippocampus, they failed to generate granule cell neurons [74], but would aNSCs from the anterior SVZ be able to integrate into the posterior SVZ and generate local cell types and vice versa? In the HSC field, different stem cell populations can be functionally discriminated by their differential ability to repopulate the myeloablated bone marrow niche and their capacity for repeated transplantation. These paradigms have led to the identification and experimental validation of clearly defined subpopulations of stem and progenitor cells (e.g., long-term vs. short-term self-renewing stem cells, multilineage and lineage-restricted progenitors). Prospective isolation and transplantation of HSCs has been refined down to the level of single cell transplants that could repopulate the niche [75]. Single cell analyses have documented heterogeneity of HSCs and progenitor cells [76] and it will be interesting to see how this heterogeneity relates to bone marrow reconstitution studies. Paradigms to discriminate different subtypes of stem or progenitor cells are still lacking in the aNSC field. Such paradigms would not necessarily need to rely on transplantation to repopulate the niche, but they would need to allow to discriminate between long-term and short-term renewing cells. Combining such approaches in animal models with different aNSC reporters (e.g., Nestin-Cre, Ascl1-Cre, Gli1-Cre, GLAST-Cre) and long-term analysis of clonal progenies may demonstrate the capacity of these putative aNSC subtypes for long-term self-renewal and repopulation (Table 2). Recent studies indicate that Ascl1-targeted aNSCs constitute short-term self-renewing stem cells in the SGZ [30,31], but whether similar aNSC types exist in other neurogenic niches remains unclear. Multiple consecutive rounds of ablation and repopulation could be used to rigorously test the self-renewing capacity of the repopulating stem cell population. This may improve our ability to distinguish between stem and progenitor cells and shed light on putative heterogeneity of aNSCs in different neurogenic regions. 
Table 2. Mouse models used for clonal analysis. HVZ (hypothalamic ventricular zone), SVZ (subventricular zone), SGZ (subgranular zone), NSC (neural stem cell), d (day), mo (months), w (week), dpi (days post induction), mpi (months post induction), n.d. (not determined), quiescent NPs (quiescent neural progenitors) DG (dentate gyrus) GCL (granular cell layer), OB (olfactory bulb), * (additional comments can be found in Notes), $\downarrow$ (alternated), $\uparrow$ (increased), $\downarrow$ (decreased), $\leftrightarrow$ (maintained/no change).

\begin{tabular}{|c|c|c|c|c|c|c|c|c|c|}
\hline Driver & Reference & Mouse Line & Region & Quiescence & Active & $\begin{array}{l}\text { Exhaustive } \\
\text { (Short Term } \\
\text { Maintenance) }\end{array}$ & $\begin{array}{l}\text { Maintenance } \\
\text { (Long Term } \\
\text { Maintenance) }\end{array}$ & $\begin{array}{c}\text { Self- } \\
\text { Renewal }\end{array}$ & Notes \\
\hline \multirow{3}{*}{ Nestin } & \multirow{2}{*}{ [41] } & $\begin{array}{c}\text { Nestin-CreER }^{\mathrm{T} 2} \text { : } \\
\text { Z/EG }\end{array}$ & \multirow{2}{*}{ SGZ } & $\uparrow \downarrow$ & $\downarrow \uparrow$ & $\begin{array}{c}\downarrow \\
\text { Assumed- } \\
\text { activated RGLs } \\
\text { maintained at } 12 \\
\text { months }\end{array}$ & $\begin{array}{c}\uparrow \\
(12 \mathrm{mo})^{*}\end{array}$. & $\uparrow$ & $\begin{array}{l}\text { Reporter-positive radial glia-like cells displayed both } \\
\text { self-renewal properties and multipotent } \\
\text { differentiation at } 2 \text { mpi. } \\
\text { Radial glial like cells can alternate between an active } \\
\text { and quiescent state. } \\
\text { * Maintenance of some activated radial glia-like cells } \\
\text { up to } 1 \text { year. }\end{array}$ \\
\hline & & $\begin{array}{l}\text { Nestin-CreER }^{\mathrm{T} 2} \text { : } \\
\text { MADM }\end{array}$ & & $\uparrow \downarrow$ & $\downarrow \uparrow$ & $\begin{array}{l}\downarrow \\
\text { Assumed-- } \\
\text { activated RGLs } \\
\text { maintained at } 12 \\
\text { months }\end{array}$ & $\begin{array}{c}\uparrow \\
(12 \mathrm{mo})\end{array}$ & $\uparrow$ & $\begin{array}{c}\text { Frequencies of all types of clones (quiescent, } \\
\text { symmetrically self-renewed, asymmetrically } \\
\text { self-renewed, and differentiated) were comparable } \\
\text { between the Z/EG and MADM reporters. } \\
\text { However, the MADM reporter allowed for a more } \\
\text { rigorous clonal analysis of quiescent radial } \\
\text { glia-like cells. }\end{array}$ \\
\hline & [31] & $\begin{array}{l}\text { Nestin-CreER }{ }^{\mathrm{T} 2} \text { : } \\
\text { Confetti }\end{array}$ & SGZ & $\begin{array}{l}\uparrow \\
\text { (4 mpi in } 6 \text { mo old mice) } \\
\text { "by calculating the time to } \\
\text { cell-cycle entry and re-entry } \\
\text { according to power-law } \\
\text { decay fitting of clonal } \\
\text { tracings" }\end{array}$ & $\begin{array}{c}\uparrow \\
\text { (Slow) }\end{array}$ & $\downarrow$ & $\begin{array}{c}\uparrow \\
\text { (4 mpi in } 12 \text { mo } \\
\text { old mice) }\end{array}$ & $\uparrow$ & $\begin{array}{c}\text { Nestin-NSCs are longer lived and slowly generate } \\
\text { new neurons, astrocytes and NSCs. Nestin-NSCs } \\
\text { prolong their quiescence with each division and } \\
\text { switch to symmetric cell fate choice after NSC } \\
\text { homeostasis has been lost in mice around 4-6 mo } \\
\text { of age. }\end{array}$ \\
\hline
\end{tabular}


Table 2. Cont.

\begin{tabular}{|c|c|c|c|c|c|c|c|c|c|}
\hline Driver & Reference & Mouse Line & Region & Quiescence & Active & $\begin{array}{c}\text { Exhaustive } \\
\text { (Short Term } \\
\text { Maintenance) }\end{array}$ & $\begin{array}{c}\text { Maintenance } \\
\text { (Long Term } \\
\text { Maintenance) }\end{array}$ & $\begin{array}{c}\text { Self- } \\
\text { Renewal }\end{array}$ & Notes \\
\hline \multirow{3}{*}{ GLAST } & [77] & $\begin{array}{l}\text { GLAST- CreER }{ }^{\mathrm{T} 2} \text { : } \\
\text { Confetti }\end{array}$ & SVZ & $\downarrow$ & $\uparrow$ & $\uparrow$ & $\begin{array}{c}\downarrow \\
(4-6 \mathrm{mo})\end{array}$ & $\begin{array}{l}\text { n.d. } \\
\text { Suggested } \\
\text { limited self- } \\
\text { renewal }\end{array}$ & $\begin{array}{l}\text { The NSC population underwent multiple rounds of } \\
\text { division in a short time span, generating progeny } \\
\text { before becoming exhausted. While other previously } \\
\text { quiescent NSCs becomes activated to counteract the } \\
\text { decline in adult neurogenesis. }\end{array}$ \\
\hline & [78] & $\begin{array}{l}\text { GLAST-CreER R }^{\mathrm{T} 2} \text { Confetti } \\
\text { Con }\end{array}$ & SVZ & $\begin{array}{l}\text { n.d. } \\
\text { Not determined in this } \\
\text { mouse model }\end{array}$ & $\uparrow$ & $\uparrow$ & $(56 d)$ & $\begin{array}{l}\text { n.d. } \\
\text { Not } \\
\text { determined } \\
\text { in this } \\
\text { mouse } \\
\text { model }\end{array}$ & $\begin{array}{l}\text { By } 21 \mathrm{dpi} \text {, most clones consisted of progenitor cells or } \\
\text { progenitor cells and neurons. By } 56 \mathrm{dpi} \text {, the } \\
\text { proportion of clones comprised by only neurons had } \\
\text { increased. These clones were rarely found in the same } \\
\text { hemisphere as a radial astrocyte, indicating NSC } \\
\text { exhaustion to be the major terminating mechanism of } \\
\text { OB neurogenesis. }\end{array}$ \\
\hline & [55] & GLAST-CreER $^{\mathrm{T} 2}$ & SGZ & $\leftrightarrow^{*}$ & $\downarrow^{* *}$ & $\uparrow$ & $\begin{array}{c}\downarrow \\
(4 \mathrm{w})\end{array}$ & $\downarrow$ & $\begin{array}{l}* \text { Depletion of Zeb1 does not directly alter the } \\
\quad \text { quiescent population. } \\
\text { ** Active clones containing radial glia-like cell and } \\
\text { non-radial glia-like cell progenies were significantly } \\
\text { reduced, while depleted clones containing only } \\
\text { differentiated progeny were significantly increased. }\end{array}$ \\
\hline \multirow[t]{2}{*}{ Troy } & [79] & TroyGFPiresCreER & SVZ & $\leftrightarrow^{*}$ & $\begin{array}{c}\uparrow \downarrow \\
\text { Active } \\
\text { NSCs can } \\
\text { return to } \\
\text { quiescence } \\
\text { after one or } \\
\text { more } \\
\text { rounds of } \\
\text { cell } \\
\text { division }\end{array}$ & $\downarrow$ & $(32 \mathrm{w})$ & $\uparrow * *$ & $\begin{array}{c}\text { From } 14 \mathrm{dpi} \text {, and in subsequent timed points, both } \\
\text { the density of NSC retaining clones and their stem } \\
\text { cell content remained stable. } \\
\text { * Most clones consisted of a single qNSC through all } \\
\text { time points. } \\
\text { ** At early time points, clones consisted of multiple } \\
\text { Troy+ cells. Suggesting symmetric division upon } \\
\text { activation. }\end{array}$ \\
\hline & & Ki67iresCreER & SVZ & $\leftrightarrow$ & $\uparrow \downarrow^{*}$ & $\downarrow$ & $\begin{array}{c}\uparrow \\
(1 \mathrm{y})\end{array}$ & $\uparrow$ & $\begin{array}{l}{ }^{*} \text { Majority of active NSCs exit the cell cycle quickly, } \\
\text { however some expand before returning to quiescence } \\
\text { (qNSCs). These qNSCs may remain long-term to later } \\
\text { contribute to ongoing adult neurogenesis. }\end{array}$ \\
\hline VCAM1 & [80] & $\begin{array}{l}\text { VP lentivirus } \\
\text { injection in Ai14 } \\
\text { mice }\end{array}$ & SGZ & $\leftrightarrow$ & $\begin{array}{c}\uparrow \\
\text { (Slow) }\end{array}$ & $\downarrow$ & $(28 \mathrm{~d}) *$ & $\downarrow$ & $\begin{array}{l}\text { * Reporter-positive cells exhibited slow proliferation } \\
\text { with some VCAM1-expressing NSCs remaining } \\
\text { quiescent. }\end{array}$ \\
\hline Hopx & [34] & Hopx-CreER ${ }^{\mathrm{T} 2}$ & SGZ & $\uparrow$ & $\uparrow *$ & $\downarrow^{*}$ & $\left(\begin{array}{c}\uparrow \\
(12 \mathrm{mo})\end{array}\right.$ & $\uparrow$ & $\begin{array}{l}\text { Reporter-positive radial glia-like cells were quiescent } \\
\text { neural progenitors with some capacity to self-renew. } \\
\text { Notably, these qNSCs retain the capacity to re-enter } \\
\text { the cell cycle up to a year post induction. } \\
\text { *At } 4 \text { mpi, there was a large shift toward clones } \\
\text { consisting of only mature neurons, indicating that } \\
\text { some radial glia-like cells were depleted. }\end{array}$ \\
\hline
\end{tabular}




\section{Heterogeneity of Fate Choice in Stem Cell Progenies}

Indeed, the relationship between Nestin-, Ascl1-, Gli1- and GLAST-targeted aNSCs remains to be determined. Lineage tracing of Nestin-CreER ${ }^{\mathrm{T} 2}$ aNSCs show a slower, steady and non-exhaustive neurogenesis suggestive of long-term cell maintenance [43,81], something confirmed by clonal analyses studies that also detected extended quiescence with increased number of cell divisions [31,41]. On the other hand, GLAST-CreER ${ }^{\mathrm{T} 2}$ aNSCs are initially very active [82], generating new neurons in a steady (in SGZ) or additive (in SVZ) manner [19]. However, their neurogenesis is exhaustive [43], with increasing asymmetric cell divisions and depletion of their numbers over time in both neurogenic niches [77,78]. While very informative, these studies have utilized individual driver lines (Table 3) without testing if there is a change in expression of key stemness genes (such as Ascl1) in Nestinor GLAST-CreER ${ }^{\mathrm{T} 2}$ labelled cells over time, for example. In other words, there may be aNSCs that express Ascl1 initially in young animals, which promotes activation and aNSC depletion; yet, these same aNSCs may downregulate Ascl1 and upregulate Nestin or Gli1 expression with increasing age to promote extended maintenance (as described in [82]). 
Table 3. Overview of different models used for lineage tracing across different neurogenic niches, * (additional comments can be found in Notes), $\uparrow \downarrow$ (alternated), $\uparrow$ (increased), $\downarrow$ (decreased), $\leftrightarrow$ (maintained/no change).

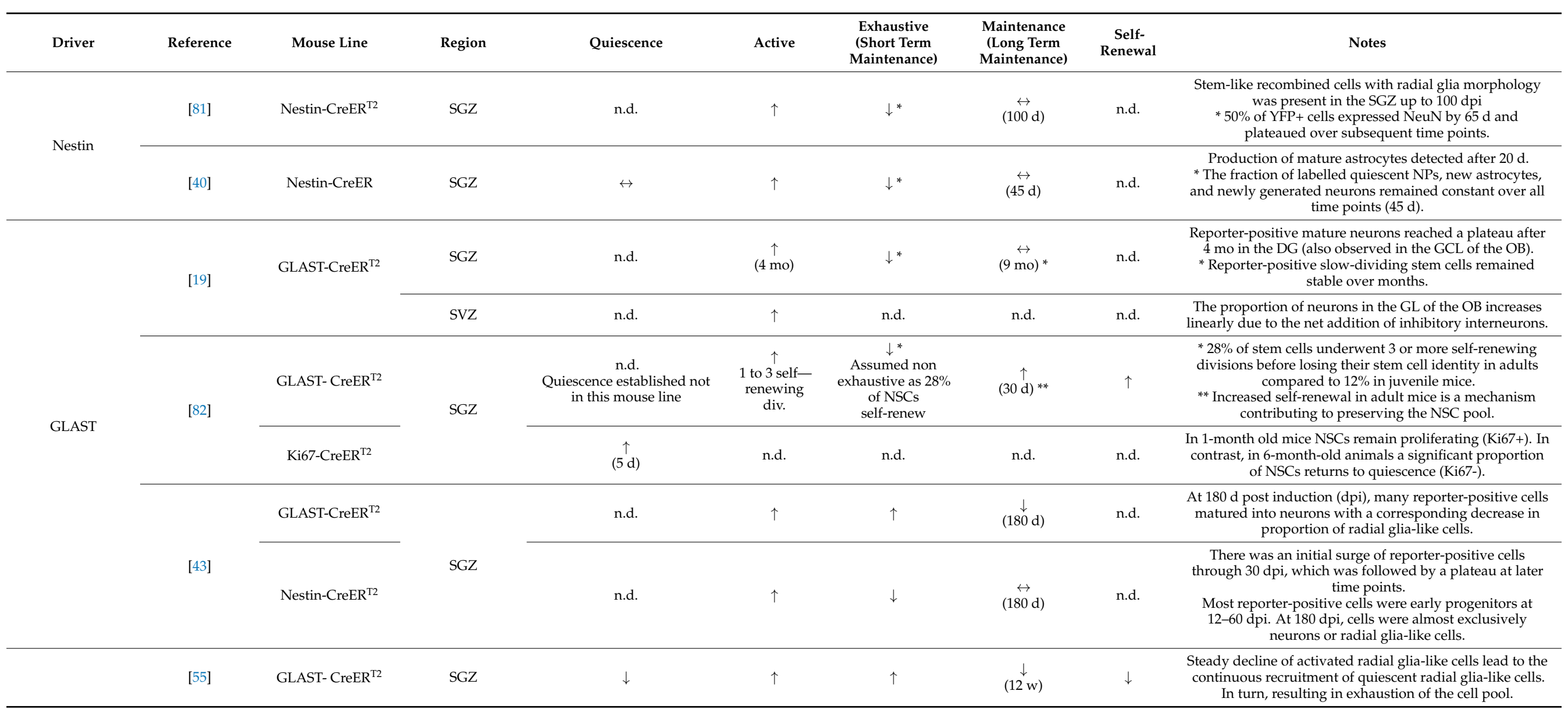


Table 3. Cont.

\begin{tabular}{|c|c|c|c|c|c|c|c|c|c|}
\hline Driver & Reference & Mouse Line & Region & Quiescence & Active & $\begin{array}{c}\text { Exhaustive } \\
\text { (Short Term } \\
\text { Maintenance) }\end{array}$ & $\begin{array}{c}\text { Maintenance } \\
\text { (Long Term } \\
\text { Maintenance) }\end{array}$ & $\begin{array}{c}\text { Self- } \\
\text { Renewal }\end{array}$ & Notes \\
\hline NG2 & [12] & NG2-CreER & HVZ & n.d. & $\uparrow$ & $\downarrow$ & $(6 \stackrel{\leftrightarrow}{(60 \mathrm{~d})}$ & $\uparrow *$ & $\begin{array}{l}\text { The absolute number of reporter positive NG2 glia } \\
\text { remained constant up to } 60 \text { dpi. However, by day } 60 \text { the } \\
\text { proportion of oligodendrocytes increased while the NG2 } \\
\text { positive glia decreased. } \\
\text { * The absolute number of NG2 glia remained constant } \\
\text { between } 7 \mathrm{~d}-60 \text { dpi, indicating that the rate of cell death or } \\
\text { differentiation was roughly the same, as they were } \\
\text { generated by self-renewing divisions. }\end{array}$ \\
\hline Fgf10 & [11] & Fgf10-CreER ${ }^{\mathrm{T} 2}$ & HVZ & n.d. & n.d. & $\begin{array}{c}\uparrow \\
\text { Number of } \mathrm{Xgal}^{+} \\
\text {tanycyes } \\
\text { drops in adult }\end{array}$ & $\begin{array}{c}\downarrow \\
(83 \mathrm{~d}) \\
\text { Number of } \\
\text { Xgal } \\
\text { tanycytes } \\
\text { drops in adult }\end{array}$ & n.d. & $\begin{array}{l}\text { The total number of reporter-positive cells found in adult } \\
\text { mice showed a small but nonsignificant drop at 39-83 d } \\
\text { compared to 24-27 d. }\end{array}$ \\
\hline \multirow{4}{*}{ Ascl1 } & [29] & Ascl1-tdTomato & SGZ & $\downarrow$ & $\uparrow$ & $\uparrow$ & $\begin{array}{c}\downarrow \\
(2 \mathrm{mo})\end{array}$ & $\begin{array}{c}\downarrow \\
\text { “self- } \\
\text { renewal } \\
\text { capacity } \\
\text { of Ascl1- } \\
\text { targeted R } \\
\text { cells is } \\
\text { tempo- } \\
\text { rally } \\
\text { limited" }\end{array}$ & $\begin{array}{l}\text { By implanting a cortical window that allowed for } \\
\text { 2-photon imaging, it was shown that, once activated, } \\
\text { Ascl1-targeted radial glia-like progenitor cells generateA a } \\
\text { burst of neurogenic activity to then commit to } \\
\text { differentiation and loss. These cells did not re-enter long } \\
\text { term quiescence. }\end{array}$ \\
\hline & \multirow{2}{*}{ [83] } & \multirow{2}{*}{ Ascl1-CreER ${ }^{\mathrm{T} 2}$} & SGZ & No change in Sox2+ cells & By $\stackrel{\downarrow}{180 \mathrm{~d}}$ & $\begin{array}{l}\quad \downarrow \\
\text { Number of Sox } 2+ \\
\text { cells }(180 \text { vs. } 30 \mathrm{~d}) \\
\text { is maintained and } \\
\text { NeuN+ cells } \\
\text { increase }\end{array}$ & $(180 \mathrm{~d})$ * & $\uparrow$ & $\begin{array}{l}\text { At } 180 \mathrm{dpi}, 65 \% \text { of reporter-positive cells were NeuN } \\
\text { positive granule neurons. However, } 25 \% \text { of } \\
\text { reporter-positive cells also expressed markers of } \\
\text { progenitor cells. } \\
\text { *No obvious loss of Sox } 2 \text { c cells indicate labeling of } \\
\text { quiescent Type- } 1 \text { cells. }\end{array}$ \\
\hline & & & SVZ & n.d. & $\uparrow$ & $\begin{array}{l}\downarrow \\
\text { Sox } 2+\text { cells } \\
\text { remained in the } \\
\text { SVZ at } 180 \mathrm{~d}\end{array}$ & $\begin{array}{c}\uparrow \\
(180 \mathrm{~d})\end{array}$ & $\uparrow$ & $\begin{array}{l}\text { At } 30 \text { dpi, many reporter-positive cells in the OB } \\
\text { co-expressed NeuN, demonstrating that labelled cells are } \\
\text { migrating and maturing. } \\
\text { * Reporter-positive cells still remained in the SVZ and } \\
\text { expressed Sox2, DCX or Ki67 up to } 180 \mathrm{~d} \text { after induction. }\end{array}$ \\
\hline & [84] & Ascl1-CreER ${ }^{\mathrm{TM}}$ & SGZ & n.d. & $\uparrow$ & $\uparrow$ & $\begin{array}{c}\downarrow \\
(180 \mathrm{~d})\end{array}$ & $\downarrow$ & $\begin{array}{l}30 \mathrm{~d} \text { after induction, } 86 \% \text { of reporter-positive cells were } \\
\text { mature neurons. This increased to } 98 \% \text { after } 6 \text { mo. } \\
\text { Ascl1 + cells were mostly identified as Type 2a progenitor } \\
\text { cells, but also a subset of stem cells with limited } \\
\text { self-renewal potential. }\end{array}$ \\
\hline
\end{tabular}


Table 3. Cont.

\begin{tabular}{|c|c|c|c|c|c|c|c|c|c|}
\hline Driver & Reference & Mouse Line & Region & Quiescence & Active & $\begin{array}{l}\text { Exhaustive } \\
\text { (Short Term } \\
\text { Maintenance) }\end{array}$ & $\begin{array}{c}\text { Maintenance } \\
\text { (Long Term } \\
\text { Maintenance) }\end{array}$ & $\begin{array}{c}\text { Self- } \\
\text { Renewal }\end{array}$ & Notes \\
\hline \multirow[b]{2}{*}{ Sox } & [85] & Sox2-CreER & SVZ, SGZ & n.d. & $\uparrow$ & $\downarrow$ & $\begin{array}{c}\uparrow \\
(4 \mathrm{mo})\end{array}$ & $\uparrow$ & $\begin{array}{l}\text { Reporter-positive cells with morphological characteristics } \\
\text { of radial glia stem cells remained abundant in both brain } \\
\text { regions up to } 4 \text { mo after induction. }\end{array}$ \\
\hline & [86] & $\begin{array}{l}\text { Sox1-tTA; LC-1; } \\
\text { R26eYFP }\end{array}$ & SGZ & $\downarrow \uparrow *$ & $\begin{array}{l}\uparrow \downarrow^{*} \\
\text { Some NSCs } \\
\text { diff., some } \\
\text { remain } \\
\text { NSCs }\end{array}$ & $\begin{array}{l}\stackrel{\downarrow}{ } \\
\text { Some Sox } 1+ \\
\text { remain NSCs }\end{array}$ & $\begin{array}{c}\uparrow \\
(18 \mathrm{w})\end{array}$ & n.d. & $\begin{array}{l}\text { *A continuous, long term }(3 \mathrm{mo}) \text { production of } \\
\text { progenitors and NBs from Sox } 1+\text { cells is consistent with a } \\
\text { stem cell population with long term neurogenic potential } \\
\text { that alternate between an activated and a quiescent state. } \\
\text { However, the decline of Sox } 1+\text { radial astrocytes after a } \\
\text { 12-week chase period indicates that some cells } \\
\text { permanently exit the stem cell pool. }\end{array}$ \\
\hline Hopx & [87] & Hopx ${ }^{C r e E R /+}$ & SGZ & $\begin{array}{l}\text { n.d. } \\
\text { Not determined in this } \\
\text { mouse model }\end{array}$ & $\uparrow$ & $\downarrow^{*}$ & $\left.\begin{array}{c}\uparrow \\
(2 \mathrm{mo})\end{array}\right)^{*}$ & n.d. & $\begin{array}{l}\text { At } 2 \text { mpi, many reporter-positive cells differentiate into } \\
\text { granule neurons and the proportion of NSCs declined. } \\
\text { *At } 2 \text { mpi Sox+ and GFAP+ NSCs derived from Hopx+ } \\
\text { NSCs were still identifiable. }\end{array}$ \\
\hline \multirow[b]{2}{*}{ Hes5 } & [88] & Hes5-CreER ${ }^{\mathrm{T} 2}$ & SGZ & n.d. & $\uparrow$ & $\downarrow^{*}$ & $(100 \mathrm{~d})^{*}$ & n.d. & $\begin{array}{l}29 \% \text { of reporter-positive NSCs remained } 100 \mathrm{~d} \text { post } \\
\text { induction, with a corresponding increase in proportion of } \\
\text { neuroblasts and postmitotic neurons. } \\
\text { * The number of NSCs remained constant over } 100 \mathrm{~d} \text { post } \\
\text { induction. }\end{array}$ \\
\hline & [89] & Hes5-CreER ${ }^{\mathrm{T} 2}$ & SVZ & $\begin{array}{l}\text { n.d. } \\
\text { Not determined in this } \\
\text { mouse model }\end{array}$ & $\uparrow$ & $\downarrow^{*}$ & $\stackrel{\uparrow}{\uparrow}$ (100 d) & $\begin{array}{l}\text { n.d. } \\
\text { Not deter- } \\
\text { mined in } \\
\text { this } \\
\text { mouse } \\
\text { model }\end{array}$ & $\begin{array}{l}\text { Reporter-positive cells in the SVZ continued to generate } \\
\text { mitotic progenitors and neuroblasts } 100 \mathrm{~d} \text { after induction. } \\
{ }^{*} \text { The neural stem cell population remained in the niche } \\
\text { over months and retained long term neurogenic potential. }\end{array}$ \\
\hline Troy & [79] & TroyGFPiresCreER & SVZ & n.d. & $\uparrow$ & $\downarrow$ & $\begin{array}{c}\uparrow \\
(1 \mathrm{y})\end{array}$ & n.d. & $\begin{array}{l}\text { Reporter-positive cells remained in the SVZ up to } 1 \text { y post } \\
\text { labelling while generating new neuroblasts. }\end{array}$ \\
\hline PDGFRb & [58] & $\begin{array}{l}\text { PDGFRb-P2A- } \\
\text { CreER }^{\text {T2 }}\end{array}$ & SVZ & $\begin{array}{l}\text { n.d. } \\
\text { Not determined under } \\
\text { physiological conditions }\end{array}$ & $\uparrow$ & $\downarrow$ & $\begin{array}{c}\uparrow \\
(4 \mathrm{mo})\end{array}$ & n.d. & $\begin{array}{l}\text { Reporter-positive radial cells (GFP+GFAP+), TAPs, and } \\
\text { migrating neuroblasts could be found within the SVZ at } \\
\text { both } 30 \text { and } 120 \text { dpi, indicating that reporter-positive stem } \\
\text { cells in the SVZ generate progeny up to } 4 \text { mpi. }\end{array}$ \\
\hline VCAM1 & [80] & $\begin{array}{l}\text { Ai14 Cre } \\
\text { (VP lentivirus } \\
\text { injection) }\end{array}$ & SGZ & $\leftrightarrow^{*}$ & $\begin{array}{l}\uparrow \\
\text { Analysed } \\
\text { only at } 28 \\
\text { dpi }\end{array}$ & $\begin{array}{l}\downarrow \\
\text { Quiescent NSCs } \\
\text { remain constant }\end{array}$ & $\begin{array}{l}\stackrel{\leftrightarrow}{(28 \mathrm{~d}) *} \\
\text { Quiescent } \\
\text { NSCs remain } \\
\text { constant }\end{array}$ & n.d. & $\begin{array}{l}\text { At } 28 \text { dpi } 31 \% \text { of reporter-positive cells were co -labelled } \\
\text { with S100 } \beta+\text { and } 67 \% \text { were NeuN positive. } \\
\text { * The ratio of quiescent NSCs that display a radial and } \\
\text { horizontal morphology remained constant from } 14 \text { dpi to } \\
28 \text { dpi. }\end{array}$ \\
\hline Spot14 & [46] & Spot14-CreER ${ }^{\mathrm{T} 2}$ & SGZ & $\begin{array}{l}\text { n.d. } \\
\text { Not determined in this } \\
\text { mouse model }\end{array}$ & $\uparrow$ & $\uparrow$ & $\begin{array}{c}\downarrow \\
(3 \mathrm{mo})^{*}\end{array}$ & $\begin{array}{l}\text { n.d. } \\
\text { Not deter- } \\
\text { mined in } \\
\text { this } \\
\text { mouse } \\
\text { model }\end{array}$ & $\begin{array}{l}\text { At } 3 \text { mpi, } 62 \% \text { of reporter-positive cells were mature } \\
\text { neurons compared to } 0 \% \text { at } 10 \text { dpi. } \\
\text { * The proportion of radial NSPCS declined from } 48 \% \text { to } \\
24 \%(10 \mathrm{~d} \text { vs. } 3 \text { mo) and non-radial NSPCs declined from } \\
50 \% \text { to } 8 \% \text {. }\end{array}$ \\
\hline
\end{tabular}


In vitro, aNSCs generate neurons, astrocytes, and oligodendrocytes [90]; demonstrating this tri-lineage differentiation is one of the standard paradigms of testing stemness in the CNS. This further suggests that potency and stemness of aNSCs are enforced by the niche and may be unlocked as in the case of reactive astrocytes [91]. In vivo, the differentiation of aNSCs progenies is more limited, often to a specific subset of neurons (see above). On one hand, this shows that aNSCs possess the general potency to produce neurons and macroglia; on the other hand, it implies that regional heterogeneity of aNSCs is driven by environmental factors, rather than cell-intrinsic programs. However, one must bear in mind that the process of extracting aNSCs for in vitro experiments is de facto an injury, which may reprogram aNSCs into a more potent state. Reactive astrocytes become more plastic when isolated and cultured in vitro [91], which may be a specific property of reactive astrocytes generated by aNSCs in response to injury [92] and similar mechanisms may act directly on aNSCs as well. Nevertheless, in vitro studies were instrumental in establishing the stem cell nature of aNSCs, particularly because demonstrating multipotency is more challenging in vivo. Similarly, extended self-renewal capacity over time is easier to demonstrate in vitro, e.g., through serial passaging.

\section{Temporal Heterogeneity of Stem Cells}

Another unresolved question is whether aNSCs phenotypes change over time. Single cell profiling highlighted largely similar transcriptional profiles of aNSCs in the hippocampus, with discernible features related to quiescent or activated states. Ascl1-targeted aNSCs in SGZ are more likely to revert to a quiescent state (reflective of a long-term self-renewing aNSC) with increasing age [82]. Thus, are these aged aNSCs still the same cell as their younger, short-term self-renewing counterparts? Would their transcriptional profiles more resemble those of long-term self-renewing aNSCs? If so, this would indicate that stem cell phenotypes can be temporarily adopted and that there is a degree of plasticity between these phenotypes, which would also fit with their largely overlapping gene expression profiles (i.e., changing only a small number of transcripts can convert short-term selfrenewing to long-term self-renewing stem cells). Parabiosis studies suggest that circulating factors affect neurogenesis levels in aged animals [93], indicating that complex interactions between aNSCs and their niche may influence stem cell phenotypes, and that age-related changes may be reversible by altering the niche. In support, circulating cytokines in the blood of younger mice increased neurogenesis levels in aged mice through remodelling of the niche [94]. It remains to be shown whether systemic factors directly act on aNSCs, and/or whether 'rejuvenation' of adult neurogenesis shifts quiescence vs. activation levels of aNSCs similar to those in younger animals. In support, blocking ageing-related tyrosine kinase signalling partially reverted aNSC quiescence [31]. We have argued that stemness is a phenotype that changes with time and interventions. Thus, environmental factors (e.g., cytokines from the blood, or age-associated changes of the brain milieu) will affect the number and type of self-renewing divisions that aNSCs undergo, influencing temporary stemness phenotypes that may be observable in younger, but not in aged, animals. Finally, ageing affects changes in aNSC differentiation patterns (e.g., reduced neurogenesis), but the underlying mechanisms remain largely unclear. A recent study demonstrated that loss of post-translational glycosylation of STAT3 results in age-associated changes of hippocampal aNSCs differentiation [95]. In addition to such cell-intrinsic mechanisms, environmental cues may also affect the altered fate of aNSC progenies in the aged brain.

\section{Technical Influences on Stem Cell Heterogeneity}

Heterogeneity of aNSCs may result from reductionistic models depending on different genetic drivers of reporter expression (or other genetic manipulation), such as the Ascl1-, GLAST-, Gli1-, and Nestin-Cre models. Partial overlap between genetic drivers in aNSCs and progenitor cells may influence the observed outcomes of stem cell divisions (discussed above). For instance, $A s c l 1$ is expressed in both long-term and short-term self-renewing aNSCs, with low Ascl1 expression in Type-1 cells of the SGZ or B cells of the SVZ and 
high Ascl1 levels in corresponding intermediate progenitor cells [83]. A seminal study directly compared Ascl1- and Gli1-targeted progenies in the hippocampus by live-cell imaging and found that only Gli1-targeted aNSCs showed long-term self-renewal [30]. As discussed above, it remains to be determined whether Ascl1 and Gli1 target different aNSC subpopulations (long-term vs. short-term self-renewing), or whether Gli1 is hierarchically superior to Ascl1. Nevertheless, these observations indicate the heterogeneity of stem cell subpopulations. We have used the GLAST-CreER ${ }^{\mathrm{T} 2}$ model [96] to trace clonal dynamics of hippocampal aNSCs and found that asymmetric divisions of aNSCs are linked to self-renewal, whereas symmetric divisions resulted in aNSC depletion [55]. We also observed clonal heterogeneity, with most clones persisting over the 4-week chase period, but approximately 1 in 5 clones terminally differentiated, comparable to a previous study [41].

\section{Regionality of Stem Cell Heterogeneity}

Ventricular neurogenic regions seem to possess more complex aNSC heterogeneity than the hippocampus. There are regionally distinct (i.e., dorsal vs. ventral) subpopulations of aNSCs in the SVZ [61]. In the adult medial-basal hypothalamus (MBH), expansion of the cell lineages occurs at the level of parenchymal progenitors [11], as is the case in the SVZ [77]. However, it remains to be determined if this is a specific cell dynamic in the cell lineage from $F g f 10$-expressing aNSCs [11], or the parenchymal expansion is a general feature in the $\mathrm{MBH}$, as it is suggested to be in the Sox2-expressing lineage [97]. The fact that adult MBH contains aNSC in both mice and humans [9] and generates new orexigenic and anorexigenic neurons has been established beyond a reasonable doubt (reviewed in [3]). However, the cell identity, stemness, and lineage progression from aNSCs to neurons in $\mathrm{MBH}$ is less clear. Using the GLAST-CreER ${ }^{\mathrm{T} 2}$ line $[19,43]$, Robins et al. showed that GLAST-expressing tanycytes, so-called $\alpha 2$, that line the dorso-medial part of $3 \mathrm{~V}$ appear first after genetic recombination that labels them and their cell progeny, suggesting that these are the aNSCs of the HVZ [12]. On the other hand, the ventral, so called $\beta$ tanycytes of the medial eminence, appear later, suggesting that they are derived from $\alpha 2$ tanycytes and may be the neural progenitors [12]. However, do $\beta$ tanycytes serve as transient progenitors or rather active aNSCs in the sense of their self-renewal and stemness? Shorter time-points after Tamoxifen induction and transgenic mouse lines specific only to tanycytes should address this question. Indeed, the unique Rax-CreER ${ }^{\mathrm{T} 2}$ line expressed in tanycytes and not in astrocytes [98] confirms that $\alpha 2$ tanycytes generate $\beta$ tanycytes [59]. However, this study also demonstrated the expansion of tanycyte-derived cells in the parenchyma, where $D C X+$ progenitors and neurons are not confined to the ventricular niche as in the SVZ [2], but dispersed in the MBH of both mice and humans [5]. Clearly, additional cell lineage tracing and clonal analysis studies are needed to determine the cell stages of the neurogenic process in the HVZ. These studies should address if there are specific aNSC subpopulations dedicated to generating discrete neuronal subtypes, as is the case in the SVZ. Finally, a combination of long-term time-lapse imaging and new, cutting-edge cell tracing technologies, such as iCOUNT [99], will address the stemness of progenitors and elucidate the relationship between cell heterogeneity and stemness.

\section{Multidimensional Model of Neurogenesis}

Results from studies on cell heterogeneity, stemness, and stem cell maintenance suggest two interpretations. First, there are discrete subpopulations of aNSCs, which generate independent clonal lineages of cell lines. Second, these apparently discrete subpopulations are a result of reductionistic technical approaches, but, in fact, they can change over time and with external influences such as disease. In other words, it remains to be tested whether some Ascl1-positive aNSCs downregulate Ascl1 and upregulate Gli1 expression over time, for example. We incline towards the second possibility, based on the observation that biological phenomena occur in gradients [100].

The linear model of adult neurogenesis assumes a one-way generation of differentiated cell progeny [48]. The conveyor belt starts from the RGC-like aNSCs and through transiently 
amplifying progenitors ends with adult-generated neurons. However, we discussed that at least some neural progenitors possess stem cell properties. In addition, two aspects of their identity remain to be directly observed. First, are there any progenitors that persist in the brain for the same duration as RGC-like aNSCs, ideally over the majority of the organism's lifespan? Second, are progenitors able to generate RGC-like aNSCs? In vivo time-lapse imaging showed neural progenitors lasting and self-renewing for several weeks $[29,30]$. However, to determine if progenitors can persist as long as quiescent aNSCs, a longer lasting in vivo time-lapse imaging would need to be combined with a clonal analysis based on a gene, which is expressed exclusively in progenitors but not in aNSCs. Unfortunately, SGZ progenitors (Type-2a cells) share cell markers with aNSCs (Type-1 cells) [101]. The best option for a progenitor-specific cell marker may be Tbr2, which is expressed in neural progenitors. A transgenic inducible Tbr2-2A-CreER ${ }^{\mathrm{T2}}$ line is available [102], however, to our knowledge, has not been used for lineage tracing in adult neurogenesis.

The prospect of progenitors generating stem cells seems unlikely at first glance. This is because our established perception of aNSCs is heavily dependent on morphological criteria, which dictate that aNSCs should have RGC-like morphology [103]. In addition, RGClike aNSCs remain the main surviving cell stage after ablation of neurogenesis $[43,69,71]$, suggesting that they are the stem cells. Therefore, it seems absurd, almost sacrilegious to suggest that progenitors not only act as NSCs but generate RGC-like aNSCs. However, the ablation experiments only show that a subset of RGC-like aNSCs are quiescent, whereas mitotically active aNSCs and progenitors are ablated. The ablation results do not rule out that certain progenitors have extended self-renewal. Moreover, stem cells can be generated by progenitors if we define them by their developmental status and potency [45]. To demonstrate whether progenitor cells can regenerate quiescent aNSCs, the opposite experiment would need to be performed-exclusive ablation of the non-proliferating stem cells. The recent in vivo time-lapse imaging studies [29,30], while ground-breaking and technically marvelous, take pictures once per day, an imaging frequency too low for directly observing a possible generation of RGC-like aNSCs from progenitors without the radial glia morphology. The concept that neural progenitors that do not exhibit radial glia morphology can act as stem cells is not impossible. For example, changes in Ascl1 expression over the lifespan may determine the exhaustive mode of adult neurogenesis under the assumption that Ascl1 is expressed in RGC-like aNSCs [82]. However, Ascl1 expression is stronger in progenitors than in aNSCs [83], raising the possibility that Ascl1 could label late-stage aNSCs that are on the cusp of turning into progenitors and that have already lost the radial glia morphology. This would be an alternative explanation of the limited self-renewal of Ascl1-targeted cells. This possibility that progenitors without RGC-like morphology can serve as stem cells has been clearly demonstrated during neuronal embryonal development. In developing neocortex, basal progenitors display stem cell behaviours while lacking the apical-basal connections and the standard RGC-like morphology [104].

Now, let's assume two premises. First, there is a gradient of stemness and stem cell identity in adult NSCs. Second, lineage progression may be a two-way street, at least during the initial stages. Under these two premises, we propose an alternative model of adult neurogenesis, which considers different dimensions including time, stemness and cell identity (Figure 1). In this model, aNSCs may change their identity, stemness and marker expression over time or under influence of external interventions (e.g., disease, running) and neural progenitors may serve as stem cells and may generate aNSCs. The first premise (gradients) implies a spectrum of stemness that ranges from quiescent aNSCs to self-renewing progenitor cells $[29,30]$. We may distinguish long-term and short-term self-renewing cells along this spectrum. Another implication of a stemness gradient is that there is a stochastic probability for the outcome of any stem cell division. The most likely outcome is a division that maintains the aNSC and generates a progenitor that is designated to differentiate, which may be influenced by the division plane [55]. However, occasionally, a stem cell may directly differentiate into two neurons, or a progenitor cell may reconvert into a stem cell. We observed a low percentage of clones containing only progenitors 
1 day after recombination (unpublished observation), which significantly increased with ablation of the stem cell transcription factor Zeb1 [55]. While this indicates that aNSCs occasionally undergo symmetric division to produce two progenitor cells, it does not preclude the possibility that one of these progenitors may retain a stem cell phenotype. The stochastic probability of self-renewal effectively self-limits the renewal of short-term stem or progenitor cells. If a progenitor holds a $50 \%$ chance of undergoing self-renewal with each division, the overall chance of successive self-renewing divisions decreases exponentially because the progenitor is lost as soon as it does not undergo self-renewal. The probability for each division outcome is affected by cell type, age, location of the cell, and external influences.
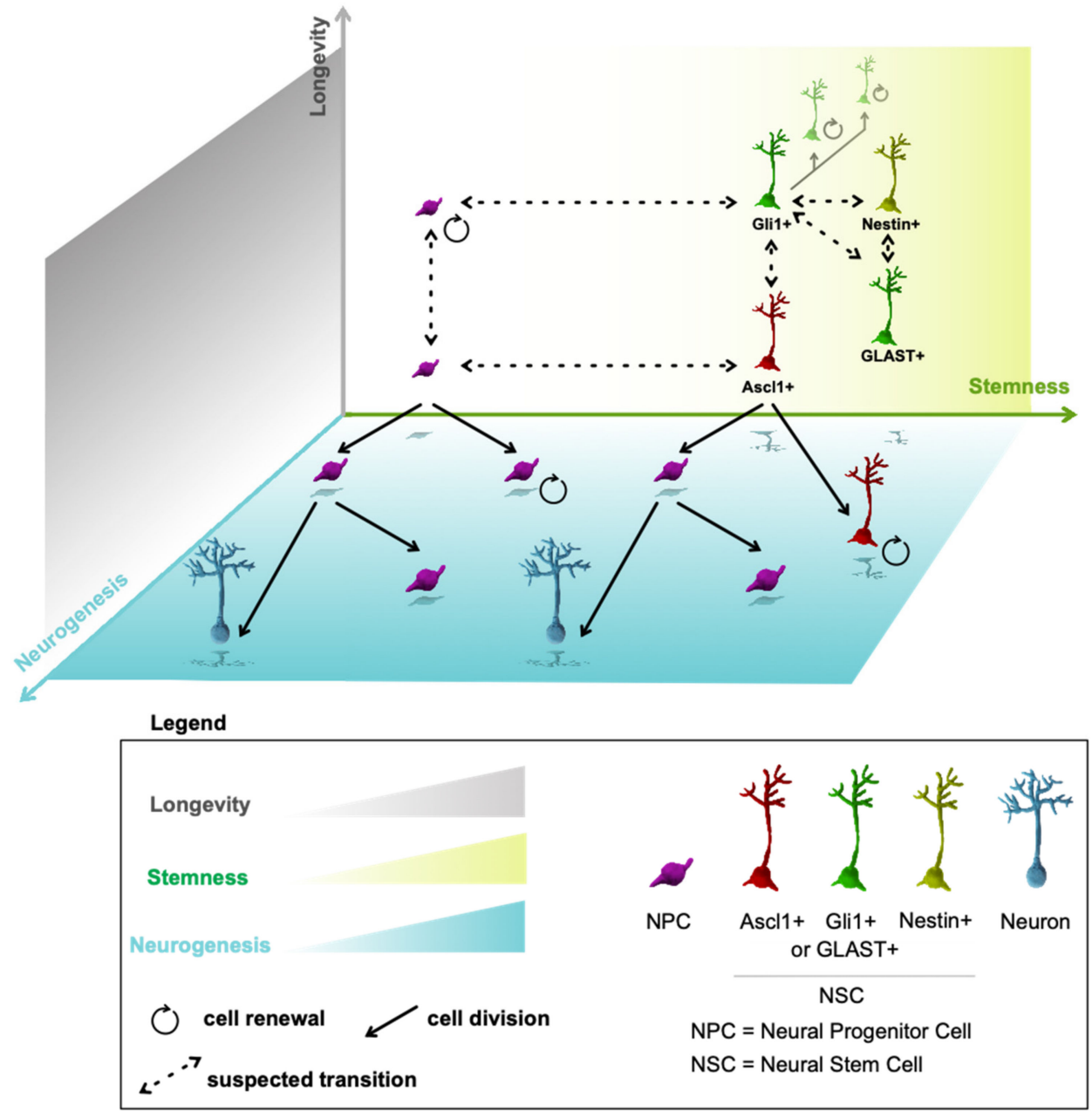

Figure 1. A multidimensional model of adult neurogenesis. Neurogenesis is conceptually asserted by three criteria: stemness, longevity of cells, and the neurogenesis process. On the plane of stemness as a function of longevity, self-renewing, long-term NSCs (such as Gli+ or Nestin+ NSCs) that last in the neurogenic niche longer are situated in the right top corner. Short-term NSCs that support exhaustive neurogenesis (such as Ascl1+ NSCs) are situated in the right bottom corner. GLAST+ NSCs reside between these two types on the stemness plane. Differentiating cell progeny of NSCs progresses on the right side of the neurogenesis plane. NPCs may acquire extended self-renewal and stem-like properties and last as long as some NSCs (in the left top corner). If NPCs self-renew only for few cell divisions (in the bottom left corner), they eventually transform into differentiating cell progeny along the horizontal plane of neurogenesis (on the left side). This process corresponds to the conveyor belt model of neurogenesis. It remains to be determined if there are long-term NPCs that can self-renew for longer periods of time. The long-term (Gli1+ and Nestin+) NSCs are also able to generate NPCs, 
however, this is not depicted to unclutter the diagram. It remains to be determined if long-term NSCs defined by a certain cell marker (i.e., Nestin) are just a segment of another long-term NSC pool (labelled by Gli1, for example) or these are truly discrete cell populations. Similarly, it remains to be determined if long-term NSCs can change their phenotype to short-term NSCs (i.e., Ascl1+ or GLAST+) and vice versa.

In conclusion, aNSCs and neural progenitors reside along a spectrum of stemness, which affects their ability to self-renew over extended periods. Likewise, regionally heterogeneous aNSCs align along a spectrum of gene expression profiles that are similar but not identical. Therefore, a singular adult neural stem cell does not exist.

Author Contributions: Conceptualization, D.P. and F.A.S.; data curation, S.J. and V.E.; writingoriginal draft preparation, D.P. and F.A.S.; writing-review and editing, D.P. and F.A.S. All authors have read and agreed to the published version of the manuscript.

Funding: This research was funded by MRC, grant number MR/S007709/1 to F.A.S.

Institutional Review Board Statement: Not applicable.

Informed Consent Statement: Not applicable.

Data Availability Statement: Not applicable.

Acknowledgments: Art\&Science, Dorotea Fracchiolla is the author of the illustration in Figure 1.

Conflicts of Interest: The authors declare no conflict of interest.

\section{References}

1. Gage, F.H. Adult neurogenesis in mammals. Science 2019, 364, 827-828. [CrossRef]

2. Obernier, K.; Alvarez-Buylla, A. Neural stem cells: Origin, heterogeneity and regulation in the adult mammalian brain. Development 2019, 146, dev156059. [CrossRef]

3. Yoo, S.; Blackshaw, S. Regulation and function of neurogenesis in the adult mammalian hypothalamus. Prog. Neurobiol. 2018, 170, 53-66. [CrossRef]

4. Xu, Y.; Tamamaki, N.; Noda, T.; Kimura, K.; Itokazu, Y.; Matsumoto, N.; Dezawa, M.; Ide, C. Neurogenesis in the ependymal layer of the adult rat 3rd ventricle. Exp. Neurol. 2005, 192, 251-264. [CrossRef]

5. Batailler, M.; Droguerre, M.; Baroncini, M.; Fontaine, C.; Prevot, V.; Migaud, M. DCX-expressing cells in the vicinity of the hypothalamic neurogenic niche: A comparative study between mouse, sheep, and human tissues. J. Comp. Neurol. 2014, 522, 1966-1985. [CrossRef]

6. Koopman, A.C.M.; Taziaux, M.; Bakker, J. Age-related changes in the morphology of tanycytes in the human female infundibular nucleus/median eminence. J. Neuroendocrinol. 2017, 29. [CrossRef]

7. Sidibe, A.; Mullier, A.; Chen, P.; Baroncini, M.; Boutin, J.A.; Delagrange, P.; Prevot, V.; Jockers, R. Expression of the orphan GPR50 protein in rodent and human dorsomedial hypothalamus, tanycytes and median eminence. J. Pineal Res. 2010, 48, 263-269. [CrossRef]

8. Baroncini, M.; Allet, C.; Leroy, D.; Beauvillain, J.C.; Francke, J.P.; Prevot, V. Morphological evidence for direct interaction between gonadotrophin-releasing hormone neurones and astroglial cells in the human hypothalamus. J. Neuroendocrinol. 2007, 19, 691-702. [CrossRef]

9. Pellegrino, G.; Trubert, C.; Terrien, J.; Pifferi, F.; Leroy, D.; Loyens, A.; Migaud, M.; Baroncini, M.; Maurage, C.A.; Fontaine, C.; et al. A comparative study of the neural stem cell niche in the adult hypothalamus of human, mouse, rat and gray mouse lemur (Microcebus murinus). J. Comp. Neurol. 2018, 526, 1419-1443. [CrossRef]

10. Chaker, Z.; George, C.; Petrovska, M.; Caron, J.B.; Lacube, P.; Caille, I.; Holzenberger, M. Hypothalamic neurogenesis persists in the aging brain and is controlled by energy-sensing IGF-I pathway. Neurobiol. Aging 2016, 41, 64-72. [CrossRef]

11. Haan, N.; Goodman, T.; Najdi-Samiei, A.; Stratford, C.M.; Rice, R.; El Agha, E.; Bellusci, S.; Hajihosseini, M.K. Fgf10-expressing tanycytes add new neurons to the appetite/energy-balance regulating centers of the postnatal and adult hypothalamus. $J$. Neurosci. 2013, 33, 6170-6180. [CrossRef] [PubMed]

12. Robins, S.C.; Stewart, I.; McNay, D.E.; Taylor, V.; Giachino, C.; Goetz, M.; Ninkovic, J.; Briancon, N.; Maratos-Flier, E.; Flier, J.S.; et al. alpha-Tanycytes of the adult hypothalamic third ventricle include distinct populations of FGF-responsive neural progenitors. Nat. Commun. 2013, 4, 2049. [CrossRef] [PubMed]

13. Saaltink, D.J.; Havik, B.; Verissimo, C.S.; Lucassen, P.J.; Vreugdenhil, E. Doublecortin and doublecortin-like are expressed in overlapping and non-overlapping neuronal cell population: Implications for neurogenesis. J. Comp. Neurol. 2012, 520, $2805-2823$. [CrossRef] 
14. Saaltink, D.J.; van Zwet, E.W.; Vreugdenhil, E. Doublecortin-Like is Implicated in Adult Hippocampal Neurogenesis and in Motivational Aspects to Escape from an Aversive Environment in Male Mice. eNeuro 2020, 7, ENEURO.0324-19.2020. [CrossRef]

15. Brus, M.; Keller, M.; Levy, F. Temporal features of adult neurogenesis: Differences and similarities across mammalian species. Front. Neurosci. 2013, 7, 135. [CrossRef]

16. Petrik, D.; Encinas, J.M. Perspective: Of Mice and Men-How Widespread Is Adult Neurogenesis? Front. Neurosci. 2019, 13, 923. [CrossRef]

17. Kornack, D.R.; Rakic, P. Continuation of neurogenesis in the hippocampus of the adult macaque monkey. Proc. Natl. Acad. Sci. USA 1999, 96, 5768-5773. [CrossRef]

18. Spalding, K.L.; Bergmann, O.; Alkass, K.; Bernard, S.; Salehpour, M.; Huttner, H.B.; Bostrom, E.; Westerlund, I.; Vial, C.; Buchholz, B.A.; et al. Dynamics of hippocampal neurogenesis in adult humans. Cell 2013, 153, 1219-1227. [CrossRef]

19. Ninkovic, J.; Mori, T.; Gotz, M. Distinct modes of neuron addition in adult mouse neurogenesis. J. Neurosci. 2007, $27,10906-10911$. [CrossRef]

20. Augusto-Oliveira, M.; Arrifano, G.P.F.; Malva, J.O.; Crespo-Lopez, M.E. Adult Hippocampal Neurogenesis in Different Taxonomic Groups: Possible Functional Similarities and Striking Controversies. Cells 2019, 8, 125. [CrossRef]

21. Lois, C.; Alvarez-Buylla, A. Long-distance neuronal migration in the adult mammalian brain. Science 1994, 264, 1145-1148 [CrossRef] [PubMed]

22. Imayoshi, I.; Sakamoto, M.; Ohtsuka, T.; Kageyama, R. Continuous neurogenesis in the adult brain. Dev. Growth Differ. 2009, 51, 379-386. [CrossRef] [PubMed]

23. Migaud, M.; Batailler, M.; Segura, S.; Duittoz, A.; Franceschini, I.; Pillon, D. Emerging new sites for adult neurogenesis in the mammalian brain: A comparative study between the hypothalamus and the classical neurogenic zones. Eur. J. Neurosci. 2010, 32, 2042-2052. [CrossRef] [PubMed]

24. McNay, D.E.; Briancon, N.; Kokoeva, M.V.; Maratos-Flier, E.; Flier, J.S. Remodeling of the arcuate nucleus energy-balance circuit is inhibited in obese mice. J. Clin. Investig. 2012, 122, 142-152. [CrossRef]

25. Cameron, H.A.; McKay, R.D. Adult neurogenesis produces a large pool of new granule cells in the dentate gyrus. J. Comp. Neurol. 2001, 435, 406-417. [CrossRef]

26. Jabes, A.; Lavenex, P.B.; Amaral, D.G.; Lavenex, P. Quantitative analysis of postnatal neurogenesis and neuron number in the macaque monkey dentate gyrus. Eur. J. Neurosci. 2010, 31, 273-285. [CrossRef]

27. Till, J.E.; Mc, C.E. A direct measurement of the radiation sensitivity of normal mouse bone marrow cells. Radiat. Res. 1961, 14, 213-222. [CrossRef]

28. Becker, A.J.; Mc, C.E.; Till, J.E. Cytological demonstration of the clonal nature of spleen colonies derived from transplanted mouse marrow cells. Nature 1963, 197, 452-454. [CrossRef]

29. Pilz, G.A.; Bottes, S.; Betizeau, M.; Jorg, D.J.; Carta, S.; Simons, B.D.; Helmchen, F.; Jessberger, S. Live imaging of neurogenesis in the adult mouse hippocampus. Science 2018, 359, 658-662. [CrossRef]

30. Bottes, S.; Jaeger, B.N.; Pilz, G.A.; Jorg, D.J.; Cole, J.D.; Kruse, M.; Harris, L.; Korobeynyk, V.I.; Mallona, I.; Helmchen, F.; et al. Long-term self-renewing stem cells in the adult mouse hippocampus identified by intravital imaging. Nat. Neurosci. 2021, 24, 225-233. [CrossRef]

31. Ibrayeva, A.; Bay, M.; Pu, E.; Jorg, D.J.; Peng, L.; Jun, H.; Zhang, N.; Aaron, D.; Lin, C.; Resler, G.; et al. Early stem cell aging in the mature brain. Cell Stem Cell 2021, 28, 955-966.e957. [CrossRef] [PubMed]

32. Altman, J.; Bayer, S.A. Migration and distribution of two populations of hippocampal granule cell precursors during the perinatal and postnatal periods. J. Comp. Neurol. 1990, 301, 365-381. [CrossRef] [PubMed]

33. Youssef, M.; Krish, V.S.; Kirshenbaum, G.S.; Atsak, P.; Lass, T.J.; Lieberman, S.R.; Leonardo, E.D.; Dranovsky, A. Ablation of proliferating neural stem cells during early life is sufficient to reduce adult hippocampal neurogenesis. Hippocampus 2018, 28 , 586-601. [CrossRef]

34. Berg, D.A.; Su, Y.; Jimenez-Cyrus, D.; Patel, A.; Huang, N.; Morizet, D.; Lee, S.; Shah, R.; Ringeling, F.R.; Jain, R.; et al. A Common Embryonic Origin of Stem Cells Drives Developmental and Adult Neurogenesis. Cell 2019, 177, 654-668.e615. [CrossRef] [PubMed]

35. Malatesta, P.; Hartfuss, E.; Gotz, M. Isolation of radial glial cells by fluorescent-activated cell sorting reveals a neuronal lineage. Development 2000, 127, 5253-5263. [CrossRef]

36. Merkle, F.T.; Tramontin, A.D.; Garcia-Verdugo, J.M.; Alvarez-Buylla, A. Radial glia give rise to adult neural stem cells in the subventricular zone. Proc. Natl. Acad. Sci. USA 2004, 101, 17528-17532. [CrossRef]

37. Fuentealba, L.C.; Rompani, S.B.; Parraguez, J.I.; Obernier, K.; Romero, R.; Cepko, C.L.; Alvarez-Buylla, A. Embryonic Origin of Postnatal Neural Stem Cells. Cell 2015, 161, 1644-1655. [CrossRef]

38. Mirzadeh, Z.; Kusne, Y.; Duran-Moreno, M.; Cabrales, E.; Gil-Perotin, S.; Ortiz, C.; Chen, B.; Garcia-Verdugo, J.M.; Sanai, N.; Alvarez-Buylla, A. Bi- and uniciliated ependymal cells define continuous floor-plate-derived tanycytic territories. Nat. Commun. 2017, 8, 13759. [CrossRef]

39. Placzek, M.; Briscoe, J. The floor plate: Multiple cells, multiple signals. Nat. Rev. Neurosci. 2005, 6, 230-240. [CrossRef]

40. Encinas, J.M.; Michurina, T.V.; Peunova, N.; Park, J.H.; Tordo, J.; Peterson, D.A.; Fishell, G.; Koulakov, A.; Enikolopov, G. Division-coupled astrocytic differentiation and age-related depletion of neural stem cells in the adult hippocampus. Cell Stem Cell 2011, 8, 566-579. [CrossRef] 
41. Bonaguidi, M.A.; Wheeler, M.A.; Shapiro, J.S.; Stadel, R.P.; Sun, G.J.; Ming, G.L.; Song, H. In vivo clonal analysis reveals self-renewing and multipotent adult neural stem cell characteristics. Cell 2011, 145, 1142-1155. [CrossRef]

42. Kempermann, G. The pessimist's and optimist's views of adult neurogenesis. Cell 2011, 145, 1009-1011. [CrossRef]

43. DeCarolis, N.A.; Mechanic, M.; Petrik, D.; Carlton, A.; Ables, J.L.; Malhotra, S.; Bachoo, R.; Gotz, M.; Lagace, D.C.; Eisch, A.J. In vivo contribution of nestin- and GLAST-lineage cells to adult hippocampal neurogenesis. Hippocampus 2013, 23, 708-719. [CrossRef]

44. Seaberg, R.M.; van der Kooy, D. Stem and progenitor cells: The premature desertion of rigorous definitions. Trends Neurosci. 2003, 26, 125-131. [CrossRef]

45. Slack, J.M.W. What is a stem cell? Wiley Interdiscip. Rev. Dev. Biol. 2018, 7, e323. [CrossRef]

46. Knobloch, M.; Braun, S.M.; Zurkirchen, L.; von Schoultz, C.; Zamboni, N.; Arauzo-Bravo, M.J.; Kovacs, W.J.; Karalay, O.; Suter, U.; Machado, R.A.; et al. Metabolic control of adult neural stem cell activity by Fasn-dependent lipogenesis. Nature 2013, 493, 226-230. [CrossRef]

47. Borrell, V. Recent advances in understanding neocortical development. F1000Res 2019, 8, 1791. [CrossRef]

48. Kempermann, G.; Jessberger, S.; Steiner, B.; Kronenberg, G. Milestones of neuronal development in the adult hippocampus. Trends Neurosci. 2004, 27, 447-452. [CrossRef]

49. Siminovitch, L.; McCulloch, E.A.; Till, J.E. The Distribution of Colony-Forming Cells among Spleen Colonies. J. Cell Comp. Physiol. 1963, 62, 327-336. [CrossRef]

50. Wilson, A.; Laurenti, E.; Oser, G.; van der Wath, R.C.; Blanco-Bose, W.; Jaworski, M.; Offner, S.; Dunant, C.F.; Eshkind, L.; Bockamp, E.; et al. Hematopoietic stem cells reversibly switch from dormancy to self-renewal during homeostasis and repair. Cell 2008, 135, 1118-1129. [CrossRef]

51. Reeve, R.L.; Yammine, S.Z.; Morshead, C.M.; van der Kooy, D. Quiescent Oct4(+) Neural Stem Cells (NSCs) Repopulate Ablated Glial Fibrillary Acidic Protein(+) NSCs in the Adult Mouse Brain. Stem Cells 2017, 35, 2071-2082. [CrossRef] [PubMed]

52. Kempermann, G. The neurogenic reserve hypothesis: What is adult hippocampal neurogenesis good for? Trends Neurosci. 2008, 31, 163-169. [CrossRef] [PubMed]

53. Gotz, M.; Sirko, S.; Beckers, J.; Irmler, M. Reactive astrocytes as neural stem or progenitor cells: In vivo lineage, In vitro potential, and Genome-wide expression analysis. Glia 2015, 63, 1452-1468. [CrossRef] [PubMed]

54. Trinchero, M.F.; Giacomini, D.; Schinder, A.F. Dynamic interplay between GABAergic networks and developing neurons in the adult hippocampus. Curr. Opin. Neurobiol. 2021, 69, 124-130. [CrossRef]

55. Gupta, B.; Errington, A.C.; Jimenez-Pascual, A.; Eftychidis, V.; Brabletz, S.; Stemmler, M.P.; Brabletz, T.; Petrik, D.; Siebzehnrubl, F.A. The transcription factor ZEB1 regulates stem cell self-renewal and cell fate in the adult hippocampus. Cell Rep. 2021, 36, 109588. [CrossRef]

56. Merkle, F.T.; Fuentealba, L.C.; Sanders, T.A.; Magno, L.; Kessaris, N.; Alvarez-Buylla, A. Adult neural stem cells in distinct microdomains generate previously unknown interneuron types. Nat. Neurosci. 2014, 17, 207-214. [CrossRef]

57. Ninkovic, J.; Steiner-Mezzadri, A.; Jawerka, M.; Akinci, U.; Masserdotti, G.; Petricca, S.; Fischer, J.; von Holst, A.; Beckers, J.; Lie, C.D.; et al. The BAF complex interacts with Pax6 in adult neural progenitors to establish a neurogenic cross-regulatory transcriptional network. Cell Stem Cell 2013, 13, 403-418. [CrossRef]

58. Delgado, A.C.; Maldonado-Soto, A.R.; Silva-Vargas, V.; Mizrak, D.; von Kanel, T.; Tan, K.R.; Paul, A.; Madar, A.; Cuervo, H.; Kitajewski, J.; et al. Release of stem cells from quiescence reveals gliogenic domains in the adult mouse brain. Science 2021, 372, 1205-1209. [CrossRef]

59. Yoo, S.; Kim, J.; Lyu, P.; Hoang, T.V.; Ma, A.; Trinh, V.; Dai, W.; Jiang, L.; Leavey, P.; Duncan, L.; et al. Control of neurogenic competence in mammalian hypothalamic tanycytes. Sci. Adv. 2021, 7, eabg3777. [CrossRef]

60. Mizrak, D.; Levitin, H.M.; Delgado, A.C.; Crotet, V.; Yuan, J.; Chaker, Z.; Silva-Vargas, V.; Sims, P.A.; Doetsch, F. Single-Cell Analysis of Regional Differences in Adult V-SVZ Neural Stem Cell Lineages. Cell Rep. 2019, 26, 394-406.e395. [CrossRef]

61. Cebrian-Silla, A.; Nascimento, M.A.; Redmond, S.A.; Mansky, B.; Wu, D.; Obernier, K.; Romero Rodriguez, R.; Gonzalez-Granero, S.; Garcia-Verdugo, J.M.; Lim, D.A.; et al. Single-cell analysis of the ventricular-subventricular zone reveals signatures of dorsal and ventral adult neurogenesis. Elife 2021, 10, e67436. [CrossRef] [PubMed]

62. Shin, J.; Berg, D.A.; Zhu, Y.; Shin, J.Y.; Song, J.; Bonaguidi, M.A.; Enikolopov, G.; Nauen, D.W.; Christian, K.M.; Ming, G.L.; et al Single-Cell RNA-Seq with Waterfall Reveals Molecular Cascades underlying Adult Neurogenesis. Cell Stem Cell 2015, 17, 360-372. [CrossRef] [PubMed]

63. Artegiani, B.; Lyubimova, A.; Muraro, M.; van Es, J.H.; van Oudenaarden, A.; Clevers, H. A Single-Cell RNA Sequencing Study Reveals Cellular and Molecular Dynamics of the Hippocampal Neurogenic Niche. Cell Rep. 2017, 21, 3271-3284. [CrossRef] [PubMed]

64. Hochgerner, H.; Zeisel, A.; Lonnerberg, P.; Linnarsson, S. Conserved properties of dentate gyrus neurogenesis across postnatal development revealed by single-cell RNA sequencing. Nat. Neurosci. 2018, 21, 290-299. [CrossRef]

65. Batiuk, M.Y.; Martirosyan, A.; Wahis, J.; de Vin, F.; Marneffe, C.; Kusserow, C.; Koeppen, J.; Viana, J.F.; Oliveira, J.F.; Voet, T.; et al Identification of region-specific astrocyte subtypes at single cell resolution. Nat. Commun. 2020, 11, 1220. [CrossRef]

66. Dulken, B.W.; Leeman, D.S.; Boutet, S.C.; Hebestreit, K.; Brunet, A. Single-Cell Transcriptomic Analysis Defines Heterogeneity and Transcriptional Dynamics in the Adult Neural Stem Cell Lineage. Cell Rep. 2017, 18, 777-790. [CrossRef] 
67. Xie, X.P.; Laks, D.R.; Sun, D.; Poran, A.; Laughney, A.M.; Wang, Z.; Sam, J.; Belenguer, G.; Farinas, I.; Elemento, O.; et al. High-resolution mouse subventricular zone stem-cell niche transcriptome reveals features of lineage, anatomy, and aging. Proc. Natl. Acad. Sci. USA 2020, 117, 31448-31458. [CrossRef]

68. Mizrak, D.; Bayin, N.S.; Yuan, J.; Liu, Z.; Suciu, R.M.; Niphakis, M.J.; Ngo, N.; Lum, K.M.; Cravatt, B.F.; Joyner, A.L.; et al. Single-Cell Profiling and SCOPE-Seq Reveal Lineage Dynamics of Adult Ventricular-Subventricular Zone Neurogenesis and NOTUM as a Key Regulator. Cell Rep. 2020, 31, 107805. [CrossRef]

69. Yuzwa, S.A.; Borrett, M.J.; Innes, B.T.; Voronova, A.; Ketela, T.; Kaplan, D.R.; Bader, G.D.; Miller, F.D. Developmental Emergence of Adult Neural Stem Cells as Revealed by Single-Cell Transcriptional Profiling. Cell Rep. 2017, 21, 3970-3986. [CrossRef]

70. Seri, B.; Garcia-Verdugo, J.M.; McEwen, B.S.; Alvarez-Buylla, A. Astrocytes give rise to new neurons in the adult mammalian hippocampus. J. Neurosci. 2001, 21, 7153-7160. [CrossRef]

71. Egeland, M.; Guinaudie, C.; Du Preez, A.; Musaelyan, K.; Zunszain, P.A.; Fernandes, C.; Pariante, C.M.; Thuret, S. Depletion of adult neurogenesis using the chemotherapy drug temozolomide in mice induces behavioural and biological changes relevant to depression. Transl. Psychiatry 2017, 7, e1101. [CrossRef] [PubMed]

72. Monje, M.L.; Mizumatsu, S.; Fike, J.R.; Palmer, T.D. Irradiation induces neural precursor-cell dysfunction. Nat. Med. 2002, 8 , 955-962. [CrossRef]

73. Doetsch, F.; Caille, I.; Lim, D.A.; Garcia-Verdugo, J.M.; Alvarez-Buylla, A. Subventricular zone astrocytes are neural stem cells in the adult mammalian brain. Cell 1999, 97, 703-716. [CrossRef]

74. Chen, X.; Tolkovsky, A.M.; Herbert, J. Cell origin and culture history determine successful integration of neural precursor transplants into the dentate gyrus of the adult rat. PLoS ONE 2011, 6, e17072. [CrossRef] [PubMed]

75. Krause, D.S.; Theise, N.D.; Collector, M.I.; Henegariu, O.; Hwang, S.; Gardner, R.; Neutzel, S.; Sharkis, S.J. Multi-organ, multi-lineage engraftment by a single bone marrow-derived stem cell. Cell 2001, 105, 369-377. [CrossRef]

76. Buenrostro, J.D.; Corces, M.R.; Lareau, C.A.; Wu, B.; Schep, A.N.; Aryee, M.J.; Majeti, R.; Chang, H.Y.; Greenleaf, W.J. Integrated Single-Cell Analysis Maps the Continuous Regulatory Landscape of Human Hematopoietic Differentiation. Cell 2018, 173, 1535-1548.e1516. [CrossRef]

77. Calzolari, F.; Michel, J.; Baumgart, E.V.; Theis, F.; Gotz, M.; Ninkovic, J. Fast clonal expansion and limited neural stem cell self-renewal in the adult subependymal zone. Nat. Neurosci. 2015, 18, 490-492. [CrossRef]

78. Bast, L.; Calzolari, F.; Strasser, M.K.; Hasenauer, J.; Theis, F.J.; Ninkovic, J.; Marr, C. Increasing Neural Stem Cell Division Asymmetry and Quiescence Are Predicted to Contribute to the Age-Related Decline in Neurogenesis. Cell Rep. 2018, 25, 3231-3240.e3238. [CrossRef]

79. Basak, O.; Krieger, T.G.; Muraro, M.J.; Wiebrands, K.; Stange, D.E.; Frias-Aldeguer, J.; Rivron, N.C.; van de Wetering, M.; van Es, J.H.; van Oudenaarden, A.; et al. Troy+ brain stem cells cycle through quiescence and regulate their number by sensing niche occupancy. Proc. Natl. Acad. Sci. USA 2018, 115, E610-E619. [CrossRef]

80. Wang, D.Y.; Luo, A.F.; Bai, Q.R.; Gong, X.L.; Zheng, Y.; Shen, Q.; Hu, X.L.; Wang, X.M. VCAM1 Labels a Subpopulation of Neural Stem Cells in the Adult Hippocampus and Contributes to Spatial Memory. Stem Cell Rep. 2020, 14, 1093-1106. [CrossRef]

81. Lagace, D.C.; Whitman, M.C.; Noonan, M.A.; Ables, J.L.; DeCarolis, N.A.; Arguello, A.A.; Donovan, M.H.; Fischer, S.J.; Farnbauch, L.A.; Beech, R.D.; et al. Dynamic contribution of nestin-expressing stem cells to adult neurogenesis. J. Neurosci. 2007, 27, 12623-12629. [CrossRef] [PubMed]

82. Harris, L.; Rigo, P.; Stiehl, T.; Gaber, Z.B.; Austin, S.H.L.; Masdeu, M.D.M.; Edwards, A.; Urban, N.; Marciniak-Czochra, A.; Guillemot, F. Coordinated changes in cellular behavior ensure the lifelong maintenance of the hippocampal stem cell population. Cell Stem Cell 2021, 28, 863-876.e866. [CrossRef]

83. Kim, E.J.; Ables, J.L.; Dickel, L.K.; Eisch, A.J.; Johnson, J.E. Ascl1 (Mash1) defines cells with long-term neurogenic potential in subgranular and subventricular zones in adult mouse brain. PLoS ONE 2011, 6, e18472. [CrossRef] [PubMed]

84. Kim, E.J.; Leung, C.T.; Reed, R.R.; Johnson, J.E. In vivo analysis of Ascl1 defined progenitors reveals distinct developmental dynamics during adult neurogenesis and gliogenesis. J. Neurosci. 2007, 27, 12764-12774. [CrossRef] [PubMed]

85. Kang, W.; Hebert, J.M. A Sox2 BAC transgenic approach for targeting adult neural stem cells. PLoS ONE 2012, 7, e49038. [CrossRef]

86. Venere, M.; Han, Y.G.; Bell, R.; Song, J.S.; Alvarez-Buylla, A.; Blelloch, R. Sox1 marks an activated neural stem/progenitor cell in the hippocampus. Development 2012, 139, 3938-3949. [CrossRef] [PubMed]

87. Li, D.; Takeda, N.; Jain, R.; Manderfield, L.J.; Liu, F.; Li, L.; Anderson, S.A.; Epstein, J.A. Hopx distinguishes hippocampal from lateral ventricle neural stem cells. Stem Cell Res. 2015, 15, 522-529. [CrossRef] [PubMed]

88. Lugert, S.; Vogt, M.; Tchorz, J.S.; Muller, M.; Giachino, C.; Taylor, V. Homeostatic neurogenesis in the adult hippocampus does not involve amplification of Ascl1(high) intermediate progenitors. Nat. Commun. 2012, 3, 670. [CrossRef]

89. Giachino, C.; Basak, O.; Lugert, S.; Knuckles, P.; Obernier, K.; Fiorelli, R.; Frank, S.; Raineteau, O.; Alvarez-Buylla, A.; Taylor, V. Molecular diversity subdivides the adult forebrain neural stem cell population. Stem Cells 2014, 32, 70-84. [CrossRef]

90. Weiss, S.; Dunne, C.; Hewson, J.; Wohl, C.; Wheatley, M.; Peterson, A.C.; Reynolds, B.A. Multipotent CNS stem cells are present in the adult mammalian spinal cord and ventricular neuroaxis. J. Neurosci. 1996, 16, 7599-7609. [CrossRef]

91. Sirko, S.; Behrendt, G.; Johansson, P.A.; Tripathi, P.; Costa, M.; Bek, S.; Heinrich, C.; Tiedt, S.; Colak, D.; Dichgans, M.; et al. Reactive glia in the injured brain acquire stem cell properties in response to sonic hedgehog. [corrected]. Cell Stem Cell 2013, 12, 426-439. [CrossRef] [PubMed] 
92. Faiz, M.; Sachewsky, N.; Gascon, S.; Bang, K.W.; Morshead, C.M.; Nagy, A. Adult Neural Stem Cells from the Subventricular Zone Give Rise to Reactive Astrocytes in the Cortex after Stroke. Cell Stem Cell 2015, 17, 624-634. [CrossRef] [PubMed]

93. Smith, L.K.; He, Y.; Park, J.S.; Bieri, G.; Snethlage, C.E.; Lin, K.; Gontier, G.; Wabl, R.; Plambeck, K.E.; Udeochu, J.; et al. beta2microglobulin is a systemic pro-aging factor that impairs cognitive function and neurogenesis. Nat. Med. 2015, 21, 932-937. [CrossRef] [PubMed]

94. Katsimpardi, L.; Litterman, N.K.; Schein, P.A.; Miller, C.M.; Loffredo, F.S.; Wojtkiewicz, G.R.; Chen, J.W.; Lee, R.T.; Wagers, A.J.; Rubin, L.L. Vascular and neurogenic rejuvenation of the aging mouse brain by young systemic factors. Science 2014, 344, 630-634. [CrossRef] [PubMed]

95. White, C.W., 3rd; Fan, X.; Maynard, J.C.; Wheatley, E.G.; Bieri, G.; Couthouis, J.; Burlingame, A.L.; Villeda, S.A. Age-related loss of neural stem cell O-GlcNAc promotes a glial fate switch through STAT3 activation. Proc. Natl. Acad. Sci. USA 2020, 117, 22214-22224. [CrossRef] [PubMed]

96. Mori, T.; Tanaka, K.; Buffo, A.; Wurst, W.; Kuhn, R.; Gotz, M. Inducible gene deletion in astroglia and radial glia-a valuable tool for functional and lineage analysis. Glia 2006, 54, 21-34. [CrossRef]

97. Li, J.; Tang, Y.; Cai, D. IKKbeta/NF-kappaB disrupts adult hypothalamic neural stem cells to mediate a neurodegenerative mechanism of dietary obesity and pre-diabetes. Nat. Cell Biol. 2012, 14, 999-1012. [CrossRef]

98. Pak, T.; Yoo, S.; Miranda-Angulo, A.L.; Wang, H.; Blackshaw, S. Rax-CreERT2 knock-in mice: A tool for selective and conditional gene deletion in progenitor cells and radial glia of the retina and hypothalamus. PLoS ONE 2014, 9, e90381. [CrossRef] [PubMed]

99. Denoth-Lippuner, A.; Jaeger, B.N.; Liang, T.; Royall, L.N.; Chie, S.E.; Buthey, K.; Machado, D.; Korobeynyk, V.I.; Kruse, M.; Munz, C.M.; et al. Visualization of individual cell division history in complex tissues using iCOUNT. Cell Stem Cell 2021, 28, 2020-2034.e12. [CrossRef]

100. Stapornwongkul, K.S.; Vincent, J.P. Generation of extracellular morphogen gradients: The case for diffusion. Nat. Rev. Genet. 2021, 22, 393-411. [CrossRef] [PubMed]

101. Beckervordersandforth, R.; Zhang, C.L.; Lie, D.C. Transcription-Factor-Dependent Control of Adult Hippocampal Neurogenesis. Cold Spring Harb. Perspect. Biol. 2015, 7, a018879. [CrossRef] [PubMed]

102. Huang, Z.J. The Jackson Lab: B6;129S4-Eomestm1.1(cre/ERT2)Zjh/J. JAX Depository. 2021. Available online: https://www.jax. org/strain/036301 (accessed on 30 November 2021).

103. Gebara, E.; Bonaguidi, M.A.; Beckervordersandforth, R.; Sultan, S.; Udry, F.; Gijs, P.J.; Lie, D.C.; Ming, G.L.; Song, H.; Toni, N. Heterogeneity of Radial Glia-Like Cells in the Adult Hippocampus. Stem Cells 2016, 34, 997-1010. [CrossRef] [PubMed]

104. Villalba, A.; Gotz, M.; Borrell, V. The regulation of cortical neurogenesis. Curr. Top. Dev. Biol. 2021, 142, 1-66. [CrossRef] 